\title{
Muş Tarihi: Kentsel Gelişim Merkezli Bir Yaklaşım*
}

\section{History Of Muş: An Urban Development-Centered Approach}

\author{
Mustafa Alican ${ }^{\mathrm{a}, * *}$ \\ ${ }^{a}$ Doç. Dr. Muş Alparslan Üniversitesi, Fen-Edebiyat Fakültesi, Tarih Bölümü, Muş/Türkiye. \\ ORCID: 0000-0001-5960-1079
}

\begin{tabular}{l} 
MAKALE BİLGİSI \\
Makale Geçmişi: \\
Başvuru tarihi: 01 Kasım 2020 \\
Düzeltme tarihi: 07 Kasım 2020 \\
Kabul tarihi: 09 Kasım 2020 \\
\hline Anahtar Kelimeler: \\
Muş Tarihi \\
Kentsel Gelişim \\
İstasyon Caddesi \\
Kale Mahallesi \\
Muş Alparslan Üniversitesi
\end{tabular}

ÖZ

$\mathrm{Bu}$ araştırmanın amacı, Doğu Anadolu'nun en eski şehirlerinden biri olmakla birlikte gelişme ivmesi en düşük iller arasında yer alan Muş'un kentsel gelişim merkezli bir tarihsel manzarasını sunmaktır. Çalışmada şehrin kuruluşundan itibaren geçirdiği tarihsel değişim ve dönüşümler ele alınmış, siyasî tarihine paralel bir hat üzerinden şehrin gelişim dinamiklerine temas edilmiştir. $\mathrm{Bu}$ bağlamda tarihin farklı dönemlerinde Muş'un fiziksel görünümü kelimelere dökülmeye çalışılmış ve şehre ilişkin kuşbakışı bir manzara ortaya konulmak istenmiştir. Metinde Muş'un bugününe ve yarınına dair bir perspektif belirlenmesi hedeflenmiştir.

\section{ART ICLE INFO}

\section{Article history:}

Received 01 November 2020

Received in revised form 07 November 2020

Accepted 09 November 2020

\section{Keywords:}

History Of Muş

Urban Development

İstasyon Street

Kale Quarter

Muş Alparslan University

\section{AB S T R ACT}

The aim of this research is to present an urban development centered historical landscape of Muş, which is one of the oldest cities of Eastern Anatolia and one of the provinces with the lowest development momentum. In the study it was discussed the historical changes and transformations that the city has undergone since its foundation, and touched the development dynamics of the city on a line parallel to its political history. In this context, it has been tried to be put into words the physical appearance of Muş in different periods of history and has been tried to be presented a bird's eye view of the city. In the text, it is aimed to determine a perspective on the present and future of Muş.

\section{Giriş: Mekânın Biçimlendirdiği Şehir}

Doğu Anadolu'nun Yukarı Murat bölümünde yer alan Muş, 1650 kilometrekarelik yüzölçümüyle bölgenin ikinci, ülkenin ise üçüncü büyük iç ovası olup şehir ile aynı ismi taş1yan Muş ovasının Güneydoğu Toroslar dizisi ile temas alanında ve eğimli bir yüzey üzerinde bulunmaktadır. Torosların uzantısı durumundaki Haçreş (Karaçavuş, Çavuş) dağlarının zirvelerinden biri olan 2645 metre yüksekliğine sahip Kurtik Dağı'nın kuzey yamaçlarında, Çar ve Garni derelerinin aktığı vadiler arasında kurulmuştur (1967 Muş İl Yıllığ1, 1968: 15, 17; Darkot, 1979: 745; Tuncel, 2006: 368). Şehrin, Haçreş dağlarının diğer zirvelerine ya da yüksek noktalarına kurulan kalelerden (Haspet, Muşet, Kepenek) biri olduğu anlaşılmaktadır. Tarihî devirler içerisinde tam karşısına aldığı Muş ovasına doğru ve sekiler halinde gelişme gösteren şehrin eski ve yeni kesimleri arasinda takriben 200 metre yükseklik farkı vardır. Bingöl’ü

\footnotetext{
* Bu çalışma, Çevre ve Şehircilik Bakanlığı tarafından hazırlanan şehir tarihi projesinin Muş ile ilgili kısmının yeniden yapılandırılarak genişletilmiş ve geliştirilmiş biçimidir.

** Sorumlu yazar/Corresponding author.

e-posta: alicanmustafa@gmail.com
} 
Bitlis'e bağlayan karayolu üzerinde olan Muş, aynı zamanda Muş Alparslan Üniversitesi'nin de kurulu olduğu güneybatı hattında ilerleyen Kulp karayolu ile Diyarbakır'a bağlanmaktadır. Muş ovasını yüksekten gören konumuyla, yüzyıllardır kuzeyden güneye akan Murat Nehri ile doğudan batıya akan Karasu Çayı'nın suladığı ovayı izlemekte ve bir yandan Bitlis'e doğru Rahva düzü eşiğini, bir yandan ovanın batı bağlantısını kuran Boğlan geçidini, diğer yandan ise Murat Nehri tarafindan açılmış olup Varto-Hınıs üzerinden Erzurum'a giden yolu oluşturan vadiyi gözlemektedir (1967 Muş İl Yıllığı, 1968: 31-32; Darkot, 1979: 745; Tuncel, 2006: 368-369).

Dışarıdan gelebilecek saldırılara karşı korunaklı denebilecek bir konumda olduğu görülen Muş'un ne zaman ve kimler tarafindan kurulmuş olduğu bilinmemektedir (Darkot, 1979: 745; Tuncel, 2006: 369). Bununla birlikte tarihî olarak şehrin çekirdeğini temsil eden kalenin konumu, kuruluş esnasında güvenlik kaygısının esas alındığını düşündürmektedir. Dolayısıyla, bir yerleşim merkezi olarak Muş'un çevresel faktörlere bağlı nedenlerle kurulduğunu söylemek mümkündür. Nitekim İslâm öncesi dönemde Taraunitis, Taraun ve Daron isimleri ile anılmasına (Darkot, 1979: 745; Hewsen, 2016: 46-47) ilave olarak ortaçağda Taran olarak adlandırılan ve 10. yüzyıldan itibaren İslâm kaynaklarında Târûn ve Muş isimleri ile zikredilen (Darkot, 1979: 745; Tuncel, 2006: 369; Eser, 2014: 212-213; Özdal, 2019: 114) şehrin ismine dair tartışmaların (Eser, 2014: 213 vd.) bir kısmının coğrafi göndermeler içermesi de aynı şekilde yine çevresel faktörlerin etkisine işaret etmektedir. Örneğin Muş kelimesinin İbranicede ve Süryanicede "otlak, sulak, verimli" gibi anlamlara ya da Ermenicede "duman" anlamına geldiğine yönelik iddialar (Şeref Han, 2009: 273; Salnâme-i Vilâyet-i Bitlis, 1. Def'a, 1310: 198; 1967 Muş İl Yıllığı, 1968: 39; Darkot, 1979: 745; Tuncel, 2006: 369; Eser, 2014: 214-215), şehrin isminin coğrafî ve çevresel etkilerle olan irtibatını ortaya koymaktadır. İlk iki iddiada kuşkusuz şehrin kıyısında bulunduğu ovaya gönderme yapılırken, diğer iddia ise kalenin yüksekliğine vurguda bulunmaktadır. Öte yandan şehrin isminin coğrafi ya da çevresel temelli değil, daha ziyade siyasî hadiselerle ilişkili olduğu yönünde yaklaşımların bulunduğuna da işaret edelim (1967 Muş İl Y1llığ1, 1968: 39; Darkot, 1979: 745; Tuncel, 2006: 369; Eser, 2014: 214 vd.).

Muş çevresindeki höyüklerden elde edilen buluntulardan hareketle tarihî açıdan M.Ö. 5000-6000'li yıllara kadar geri giden bir geçmişe sahip olduğu düşünülen bölgenin tarihi, şehri Urme, Ulme, Ulmeri ya da Kulmeri olarak isimlendirdikleri düşünülen Urartular dönemine kadar takip edilebilmektedir. Dolayısıyla Muş çevresindeki Urartu dönemi eserlerinin Muş tarihinin Urartular dönemine kadar götürülebileceği düşüncesini desteklediği söylenebilir (Eser, 2013: 44; Eser, 2014: 212; Tiryaki, 2019: 98). Yine şehir merkezine yakın mevkilerde varlıkları tespit edilmiş olan höyüklerde Kalkolitik, Halaf, Demir ve Tunç çağlarına, ayrıca ortaçağlara ait seramik parçalarının elde edilmiş olması (Biber, 2018: 31-50; Tiryaki, 2019: 83 vd.; ), bölgede yerleşim tarihinin tarihöncesi dönemlere indiğini göstermektedir (Tiryaki, 2019: 77). ${ }^{1}$ 1991-1993 yılları arasında Muş'un

\footnotetext{
Bölgenin tarihöncesi çağları ile ilgili olarak bkz. Rothmann, Kozbe, 1997: 105-126; Kozbe, 1995: 35-40; Özfirat, 1999: 1-22; Özfirat, 2000: 193-210; Biber, 2016: 3501-3520; Biber ve Çavuşoğlu, 2013: 303-320; Yiğitpaşa ve Can, 2012: 274-291.
}

muhtelif yerlerinde yüzey araştırmaları yapmış olan $\mathrm{M}$. Rothmann ve ekibinin çalıştığ höyüklerden biri olup şehrin tarihî merkezine en yakın konumda yer alan Tebebağı Höyük'te tespit edilen çanak çömlek parçalarının Demir Çağı'na tarihlenmiş olması ya da Muş il merkezinin birkaç kilometre güneydoğusunda bulunan Urartular dönemine ait Kepenek Kalesi, ${ }^{2}$ gerek tarihöncesi dönemlerde gerekse erken tarihî devirlerde Muş bölgesindeki yerleşimin tekil bir nitelik arz etmediğini göstermektedir (Biber, 2018: 23, 32; Tiryaki, 2019: 98). Muş, aynı dağ silsilesi üzerinde yer aldığı başka kalelerle birlikte ya da onların oluşturduğu bir yerleşim ağı içerisinde yer almış, zaman içerisinde, muhtemelen "yola yakınlığgı" dolayısıyla ön plana çıkmış ve modern dönemlerde de "yola doğru" genişlemiştir. Tam bu noktada, bir 16. yüzyıl müellifi olan Şeref Han'ın, Muş Kalesi'nin "babaları ve ataları zamanında" şehrin bir fersah (5-6 km) güneyinde olduğu ve Osmanlı hükümdarı Kanuni Sultan Süleyman tarafindan yıkılarak şimdiki yerine taşındığı yönündeki kaydını hatırlatmak ilgi çekici olabilir (Şeref Han, 2009: 273).

Van (Tuşpa) merkezli Urartuların batıya yayılma alanı içerisinde kalan Muş bölgesinin, sonraki dönemlerde Medler, Ahamenidler, Selevkoslar ve Parthların hâkimiyetine girdiğini ve M.Ö. 3. yüzyılın ortalarından itibaren Romalılar ile Partların, sonraları Romalılar ile Sâsânîlerin bitmez tükenmez mücadelelerinin devam ettiği sınır hattında kaldığını biliyoruz (Tuncel, 2006: 369; Tiryaki, 2019: 96-103). Muş ve çevresi, bölgedeki Ermeni ağırlığının siyasî olarak belirginleştiği 4. yüzyıla kadar muhtemelen bulunduğu konum itibarıyla aralıklarla el değiştirmeye devam etmiştir. Bütün bu süreç içerisinde bir şehir olarak Muş’un kıyıda ve Muş ovasının gölgesinde kaldığı, görece önemsiz konumda olduğu anlaşılmaktadır. Ermeni olmadıklarına ilişkin değerlendirmeler bulunmakla birlikte (Grousset, 2006: 279) ${ }^{3}$ Ermeni olduklarına dönük yaygın bir kanaat olan meşhur Mamigonyanlar ailesinin bölgede etkinlik kazanmaları, ailenin merkezi olduğu anlaşılan Muş'un da bir yerleşim olarak önem kazanma sürecinin başlangıcı olmuştur (Eser, 2014: 225). Muş isminin ve kalesinin ailenin en önemli figürlerinden Muşeg Mamigonyan ile ilişkilendirilmesinden (1967 Muş İl Yıllığı, 1968: 52; Eser, 2014: 220) de anlaş1labileceği gibi, Muş bölgesi bu dönemde Ermenilerle özdeşleşmiştir. Muş kale yerleşiminin güneyinde bulunan Kızıl Ziyaret Dağı'ndaki Muşet Kalesi'nin Muşeg Mamigonyan tarafindan inşa ettirildiğine dönük rivayet (Darkot, 1979: 745; Eser, 2014: 220, n. 50), 4. yüzyıldan başlayıp Müslümanların bölgeye tam manasıyla hâkim oldukları (şehrin bu 5-6 yüzyıllık dönemde birçok kez Müslümanlar ile Ermeniler arasında el değiştirdiğini biliyoruz) 11. yüzy1la kadar devam eden (Mamigonyanlardan sonra bir başka Ermeni ailesi olan Pakradunniler hâkim olmuşlardır bölgeye (Grousset, 2006: 30; Darkot, 1979: 476; Hovannisian, 2016: 10; Hewsen, 2016: 54; Eser, 2013: 51vd.)) ve Roma, Sâsanî, Bizans ve sonra Müslümanlara tabî olarak sürdürülen Ermeni hâkimiyetinin bir yansıması kabul edilmelidir. Bununla birlikte, şehrin gözümüzde canlanmasını temin edebilecek malzemenin bu dönemler için yetersiz olduğunu belirtmek gerekir.

\footnotetext{
${ }^{2}$ Kepenek Kalesi ile ilgili müstakil bir çalışma için bkz. Koçhan, N. ve Sur, C., 2003: 57-63.

${ }^{3}$ Ailenin Ermeni olmadığ 1 tezini Ermeni kaynaklarından hareketle temellendirme gayreti içerisinde olan müstakil bir metin için bkz. Bedrosian, 2014: 827-836.
} 
Ermeni kaynakları tarafından 4. yüzyıldan itibaren Daron ismiyle anılan Muş, zaman zaman şehirdeki bazı yapılara ilişkin göndermelere (Grousset, 2006: 41) denk gelinse bile "bir yerleşim birimi olmak bakımından" oldukça belirsizdir. Daron ismiyle hem Muş şehrine hem de Muş ovasına işaret ediliyor olmasına ek olarak şehrin fiziksel yapısına dair yeterli bilginin bulunmaması, bir şehir olarak Muş'un fiziksel panoramasını oluşturmaya ilişkin gayretlerin sonuca ulaşmasına engel olmaktadır. Bir başka ifadeyle, tarihöncesi çağlardan geç ortaçağlara kadar "bir kale yerleşimi" olan Muş'un tasviri pek mümkün gibi görünmemektedir. Gerek bu dönemler, gerekse ortaçağın daha sonraki devirleri bağlamında Muş'un fiziksel durumu ile alakalı en ilgi çekici bilgi, buranın hapishanesi ya da hapishaneleri ile bilindiğine işaret eden bazı bölük pörçük kayıtlardan edindiğimiz verilerdir. ${ }^{4}$ Bunun dışında şehre ilişkin elimizde bulunan en temel veri, Muş'un Muş ovasına yüksekten bakan bir konumda yer alan küçük bir yerleşim olduğudur. Siyasî ya da ticarî açıdan burayı çevrede bulunan diğer yerleşim birimlerinden ayıran kendine özgü bir niteliği yok gibidir. Nitekim şehrin bu tarihsel bulanıklığı İslâm kaynakları tarafından da desteklenmektedir.

\section{Cumhuriyet Öncesi Dönemde Muş'un Kentsel Gelişimi}

Muş’un İrminiyye bölgesinde olduğuna işaret eden İslâm kaynaklarında şehir ile alakalı çok fazla bilgi bulunmamaktadır (Özdal, 2019: 114; Eser, 2013: 46). Bununla birlikte, eldeki kısıtlı verilerden hareketle Muş'a dair bir perspektif oluşturabilmek mümkündür. Muş adıyla ilk defa Makdisî'nin Ahsenü 't-Tekâsim adı eserinde anılan şehir (Tuncel, 2006: 369; Eser, 2014: 223), İbn Vâs1l (ö. 1298) tarafindan Ahlatşah şehirleri arasında zikredilmekte (Özdal, 2019: 114), Ebû'l-Fidâ (ö. 1331) tarafindan Muşlu bir râviye atıfla "suru olmayan, bir vadinin ağzında ve dağın eteğinde küçük bir belde" (Ebü'l-Fidâ, 2017: 313) olarak tarif edilmektedir. Eserini 14. yüzyılda kaleme alıp yaşadığı dönemin siyasî coğrafyası bağlamında Muş'u Musul merkezli Diyârbekir ve Diyârrebîa bölgesi içerisinde değerlendiren İlhanlı memuru Kazvînî, şehrin eski dönemlerde Mardin'den daha büyük olduğunu, fakat kendi zamanında harap bir halde bulunduğunu belirtmiştir (Darkot, 1979: 746; Özdal, 2019: 114). Anonim Vakayinâme'de yer alan ve 1363 'te bölgede meydana gelen depremin Muş'a da büyük zarar verdiğini bildiren kayıt (Galtsyan, 2007: 304; Oktay, 2007: 304) ile uyumlu olmakla birlikte şehrin 13. yüzyılın ilk yarısında gerçekleşen Moğol istilası esnasında (Turan, 2004: 143$)^{5}$ ya da Timur'un bölgeyi işgali sırasında büyük

\footnotetext{
${ }^{4}$ Mamigonyan hâkimleri, düşmanlarını "Daron Dağı'nda" olup Kartallar Şatosu ve Keçiler Kalesi denilen "kartal yuvalarından birine" hapsederlerdi. Bkz. Grousset, 2006: 268. 12. yüzyıl sonunda Selahaddîn Eyyûbî'nin yeğeni Takiyyeddin Ömer'in Muş ovasına gelip "burada bir kalede mahpus bulunan" Ahlatşah vezirini kurtarmıştı. (...) Ahlat tahtını ele geçiren gasıp Aksungur, devirdiği Ahlatşahı'nın karısını ve oğlunun Muş’ta bir kaleye hapsetmişti. (...) Ahlatşahı Sökmen, Artuklu Belek'i Muş’ta hapsetmişti. Bkz. Turan, 2004: 34, 120-121, 164. 14. yüzyıl müellifi el-Ömerî, Aksungur'un Ahlatşahı'nın karısını ve oğlunu Muş'taki Erzas kalesine hapsettiğini belirtmektedir. Bkz. Şihabeddin b. Fazlullah el-Ömerî, 2014: 322. Şerefeddin Ali Yezdî, Zafernâme'sinde, Timur'un Yatık Sûfî'yi Muş kalesine hapsettirdiğini belirtir. Bkz. Şerefüddin Ali Yezdî, 2019: 240.

${ }^{5}$ Ermeni müverrihi Piskopos Stepanos, 1228 yllında Harezmşahlar tarafindan yıkılan şehirler arasında Muş'u da zikreder ki, Muş'un hem Harezmşahlar hem de birkaç yıl sonra Moğollar tarafindan tahrip edilmiş olduğu anlamına gelen bu kayıt, şehrin "fiziksel" sessizliğinin anlaşılması bakımından da önemli bir veridir. Bkz. Galtsyan, 2007: 63
}

zarar gördüğü (Evliyâ Çelebi, 2010: 214; 1967 Muş İl Yıllığ 1, 1968: 15; Darkot, 1979: 746) şeklindeki rivayetleri doğrulayan bir veri olarak da görülen (Darkot, 1979: 746; Tuncel, 2006: 369) bu değerlendirmenin ne kadar doğru olabileceğini anlamak zordur. 15. yüzyılda Akkoyunlu Uzun Hasan'1 ziyaret etmek için bölgeye geldiği esnada Muş'a da uğrayan Venedik elçisi Josaphat Barbaro'nun kendisinden yaklaşık bir asır önce şehrin "suru olmadığını" belirten Ebü'l-Fidâ'ya nazire yaparcasına 'küçük ve sağlam bir kaleye sahip olan Muş’un dağların arasındaki bir tepenin üzerinde yer alan ve hemen alt tarafinda bulunan halkı kalabalık şehrin çevresinin üç mil olduğunu" belirtmesinden (Barbaro, 2016: 91) ya da bir 16. yüzyıl gözlemcisinin notları olan D'aramon Seyahatnamesi'nde Muş'un “dağ üstüne kurulu küçük bir hisar" olduğuna işaret etmesinden (Chesnau, 2012: 57) de açık bir biçimde anlaşılabileceği üzere, şehir daha sonraki dönemlerde de eski "küçüklüğünü’ muhafaza etmiştir.

İslâm kaynaklarında Muş’a ilişkin fazla bilginin bulunmaması, şehrin ana trafik arterlerin dışında olması ile ilgilidir. Ortaçağda Urartular dönemine ait ulaşım hatları dönüşmüş, İran ve Azerbaycan'1 el-Cezîre ve Suriye'ye bağlayan yol Ahlat üzerinden güneybatıya sarkmıştır. Nitekim bu dönemin kervansaray dizilimi de söz konusu yargıyı doğrular niteliktedir. Dolayısıyla böylece ana ticaret güzergâhının dışında kalan Muş'a daha az seyyah ve tüccar gelmiş, buna bağlı olarak da şehre ilişkin veri üretimi kısıtlı seviyede kalmıştır (Özdal, 2019: 115). Öte yandan Muş hakkındaki kayıtların büyük kısmının bir şehir olarak Muş'a değil, bir bölge olarak Muş’a dönük olduğunu da not etmek gerekir. Bundan dolayı ortaçağ kaynaklarından edindiğimiz örneğin nüfus verileri (Muş’ta Ermeniler yaşıyordu. 9. yüzyılda evvela Araplar, daha sonra 11. yüzyılda Türkler, 13. yüzyılda Kürtler, 14. yüzyılda Oyratlar ve Zuttlar görünür oldular. (Özdal, 2019: 113)) türü bilgilerin şehrin karakterini yansıtmakta ziyade Muş ovasından gelip geçen ya da buraya yerleşen topluluklara dâir olduğu akılda tutulmalıdır. Bu durum, tıpkı daha önce olduğu gibi İslâmî dönemlerde de şehrin nasıl bir görünüme sahip olduğunun tespit edilmesini imkânsız kılmaktadır. Fakat elimizde bulunan verilerden hareketle şehre ilişkin bir bakış oluşturulabilir.

Yavuz Sultan Selim'in 1514 tarihli Çaldıran seferinin ardından Osmanlı idaresine geçen ve idarî anlamda Bitlis Sancağı'nın nahiyesi olarak yapılandırılan (1967 Muş İ Yıllığı, 1968: 15, 40; Darkot, 1979: 756; Tuncel, 2006: 369; Alanoğlu, 2019: 147; Gencer, 2019: 13 vd.) Muş’a ilişkin fiziksel belirsizlik bu dönemde de devam etmekle birlikte, günümüze kalan bazı mimarî eserlerden hareketle fazla detaylı olmasa da bir panorama çıkarabiliyoruz. 1555'te Osmanlılar ile Safevîler arasında imzalanan Amasya Anlaşması'nda sonra sancak statüsü kazandığı görülen, 1600'lü yılların ilk senelerinde tekrar nahiye olan ve 1605 tarihli tımar icmal defterinden yeniden sancak olduğu (Alanoğlu, 2019: 149, 155) anlaşılan şehrin, gelir kaynakları tahsisinden hareketle küçük bir kasaba hüviyetindeki durumu görülebilmektedir (Tuncel, 2006: 369; Alanoğlu, 2019: 149). Bu dönemde nüfusun 8 bin dolaylarında olması da Muş'un fiziksel hüviyetine ilişkin bir fikir verebilir (Halaçoğlu, 2015: 21). Nitekim bir 17. yüzyıl metni olan Cihannümâ'da Muş'un küçük bir yerleşim yeri olduğuna işaret edilmesi de buna delalet eder (Darkot, 1979: 746; Tuncel, 2006: 370). Yine bu yüzyılda bölgeye gelen meşhur seyyah Simeon'un bugün Yaygın ilçesinde bulunan Surp Karabet 
Manastırı'na gidip burada bir süre ikamet etmesine rağmen Muş'a uğrama gereğini duymamış olmasını (Polonyalı Simeon, 1964: 97 vd.) da şehrin küçük ve önemsiz oluşu ile irtibatlandırmak mümkündür. Bu dönemlerde Muş'un fiziksel karakteristiğini 14. yüzyıla ait olduğu değerlendirilen (Tuncel, 2006: 370) Ulu Camii'nin oluşturduğunu belirtebiliriz. Kalenin aşağı kısmında olan ve avlusunda medfûn bulunan Şeyh Muhammed Mağribî isimli bir zat tarafindan yaptırıldığı ve yanına bir de zaviye eklendiği kanaati yaygın olan Ulu Camii'nin 1571 tarihli vakıf defterinde Ferhad Paşa Camii olarak kayıt altına alındığı görülmektedir. Bu durumun, daha eski dönemlerde inşa edilmiş olup 16. yüzy1lda harabe halinde olan caminin 1560'lı yıllarda Muş Sancakbeyi olan Ferhad Paşa tarafından eski planına uygun biçimde yeniden inşa edilerek ibadete açılması ile irtibatlı olduğu anlaşılmaktadır (Tuncel, 2006: 370-371; Kılıç, 2004: 251-252; Alanoğlu, 2019: 149). ${ }^{6}$ Yine bu dönemin önemli eserlerinden Aslanlı Han içerisindeki Hacı Şeref Camii de şehrin kamusal yapılarından biridir. Adına ilk olarak yine 1571 tarihli vakıf defterinde rastlanan ve daha önce kilise olduğuna dâir bir iddia da bulunan caminin, Selçuklular dönemine ait olduğu sanılan ve bugün yıkık halde bulunan Aslanlı Han içerisinde yer alması dolayısıyla Selçuklu eseri olduğu tahmin edilmekte ve 16 . yüzyılda Osmanlı idaresi tarafından ihya edilerek vakıflandırıldığı anlaşılmaktadır (Kılıç 2004: 252-253; Tuncel, 2006: 371; Kulağuz, 1997: 28-35). Aynı şekilde 18. yüzyılda şehre siluet kazandıran diğer bir eseri, Alaaddin Bey Camii'ni de burada zikretmek gerekir. Muş idarecilerinden Alaaddin Bey tarafindan 1746 yılında inşa ettirilen merkezdeki bu camii ile medresesine 1 han, 1 hamam (Kulağuz, 1997: 7981), 44 dükkân ve birtakım tarlaların vakfedilmiș olması (Gencer, 2019: 225-226; Kulağuz, 1997: 36-45), şehrin sözü edilen dönemdeki fiziksel durumu hakkında da fikir verebilir. ${ }^{7}$ Ayrıca Minare Mahallesi'nin Yukarı Çarşı bölümünde 1747 yılında Hacı Yakup Efendi tarafindan bir çeşme yaptırılmış olduğunu da burada not edelim (Kulağuz, 1997: 88-89). Aynı şekilde Alaaddin Bey'in oğlu Maksut Paşa'nın da şehrin kamusal mimarisinin gelişiminde katkısı olduğu bilinmektedir. Paşa, babasının yaptırmış olduğu Alaaddin Camii'nin yanına kendi adıyla anılan bir medrese inşa ettirmiş, Tirvank köyünün gelirlerini vakfettiği bu medresenin arazisinde daha sonra yapılan 15 dükkân da Maksut Paşa Medresesi’ne vakfedilmiştir (Gencer, 2019: 227). Yine aynı ailenin Alaaddin Bey Camii'nin yanında bir çeşme yaptırdığı, Alaaddin Bey'in torunlarından Abdülkadir b. Hacı Osman'ın 1876 tarihinde Zahire Meydanı'nda bulunan bir uncu dükkânını bu çeşmeye vakfettiği de belirtilmesi gereken imar ayrıntıları arasındadır (Gencer, 2019: 228). Alaaddin Paşazadelerin Muş'taki imar faaliyetleri bu kadarla sınırlı değildir. Murat Paşa 18. yüzyılda kendi adını taşıyan bir camii ve medrese yaptırıp bu eserlere 35 dükkân ve 2 tarla vakfetmiştir (Gencer, 2019: 229). 1940'lı y1llarda yıktırılan bu cami günümüzde harabe halinde olsa da restorasyon çalışmaları devam etmektedir (http://www.mus.bel.tr/mart-ayi-meclis-toplantisi-yapildi).

Ayrıca Murat Paşa'nın oğlu Selim Paşa'nın, babasının yaptırdığı caminin yanında bulunan tekkeyi tamir ettirdiğini ve 1824 yılında Arınç köyünü buraya vakfettiğini not ede-

\footnotetext{
${ }^{6}$ Ulu Camii ile ilgili ayrıntılı bilgi için bkz. Kulağuz, 1997: 22-27.

7 Daha önce kubbesi toprak olan caminin 1961-1965 yıllarında tamir gördüğünü, mabede kurşundan bir kubbe yapıldığını ve önüne de cemaatin oturabilmesi için bir teras eklendiğini not edelim. Bkz. 1967 Muș İl yıllığı, 1968: 51 .
}

lim (Gencer, 2019: 231; Şen, 2020: 464-465). Son olarak aileden Şerif Bey'in Muş'ta kendisine elli odalık bir konak yaptırmış olduğunu da söyleyelim. Lâkin bu yapının nerede olduğu konusunda bilgimiz yoktur (Gencer, 2019: 236).

16 ve 18. yüzyıllar arasında ne türden panoramik detaylara sahip olduğunu bilmediğimiz Muş’un, kalenin alt kısmında bulunan camiler ve muhtemelen başka kamusal binalara ilaveten kalenin yamaçlarında inşa edilmiş evlerden müteşekkil bir kasaba görünümünde olduğunu tahmin edebiliriz. Bununla birlikte, 19. yüzyıla gelindiğinde şehre ilişkin verilerin artmasına bağlı olarak daha canlı tahminlerde bulunabilmek mümkündür. Özellikle bu yüzyılda şehri ziyaret eden yabancıların belli ölçüde şehir tasvirleri de ihtiva eden görece detaylı kayıtları ve Muş’un nüfusuna ilişkin temasları aydınlatıcı bir mahiyet arz etmektedir. Dolayısıyla şehrin kentsel gelişimine ilişkin bilgilerin de bu dönemde artmaya başladığı söylenebilir. Nitekim bu duruma bir örnek olarak 1830'lu yılların sonunda Muş'a gelen Horatio Southgate'in verdiği bilgiler zikredilebilir. Onun bildirdiğine göre, sokaklarda birçok Kürt olmakla birlikte bunlar şehirde ikamet etmiyordu. Bu sırada şehirde Müslümanlara ait 5 cami, 10 medrese ve 3 okul ile Ermenilere ait 5 kilise bulunuyordu. Kiliselerden birinin adı Keuk Vedavend (Kırk Adım) Kilisesi idi ve yanında bir de okul bulunan kilisenin 1300 yıllık olduğu iddia ediliyordu. Camilerden biri kiliseden çevrilmişti ve kapısının üzerinde camiye çevrildiği H. 979 (1571-1572) tarihi yer almaktaydı. Ulu Camii küçük olmasına rağmen şehrin en iyi yapısıydı. Camide Arapçadan Türkçe ve Kürtçeye çevrilmiş kitaplar bulunuyordu. Şehirde kitap satan bir yer yoktu. Öte yandan şehirde bir hamam ve küçük de olsa bir han vardı (Southgate, 1840: 203-205, 207).

Tanzimat Fermanı'nın uygulamaya konulduğu 1847 yılından itibaren muhtelif vilayetlerde ve Berlin Antlaşması'nın Doğu Anadolu'nun idarî yapısında 1slahat yapılmasını öngören maddesi doğrultusunda 1879'de Cumhuriyet dönemine dek bu şekilde kalacağ 1 Bitlis vilayetine bağlandığ görülen Muş (Tuncel, 2006: 370; Kara, 2019: 35), "birinci sınıf” (Salnâme-i Vilâyet-i Bitlis, 1. Def’a, 1310: 133) bir sancak olduğu bu dönemde Osmanlı modernleşmesine paralel olarak gelişim kaydetmiştir. Bu dönemde ekonomik gelişmişlik noktasında fazlasıyla olumsuz bir manzaraya sahip bulunan şehrin Van ve Bitlis ile birlikte Erzincan üzerinden Karadeniz sahillerine bağlanması için 1885 y1lında mühendislerin görevlendirilmiş olması (Bingül, 2019: 21), proje her ne kadar başarıya ulaşmamış olsa da önemlidir. Yetkililerin Muş'un tarihî ve müzmin sorunu olan "k1yıda kalmışlık" sorununu doğru tespit ettiklerini göstermektedir. Yine bu dönemde Muş'u bağlı olduğu vilayet merkezine bağlamak için şose yolların yapımı ile ilgili çalışmaların olduğunu da biliyoruz (Salnâme-i Vilâyet-i Bitlis, 1. Def'a, 1310: 199; Kara, 2019: 41). Öte yandan büyük çaplı olmamakla birlikte, 19. yüzyılda Muş’ta sanayi etkinliklerinin bulunduğunu da not etmek gerekir. Vilayet salnamelerinin, şehir merkezinde altın ve gümüşten tütün tabakası, sigaralık, kamçı, kama, kılıç ve muhtelif silahlar yapıldığını ya da toprak ve tenekeden çömlek, ibrik, küp, yemek tabağ1, semaver, balta, kazma ve kürek gibi aletler ile kilim imal edildiğini bildirmesi, Muş'ta canlı bir üretim sürecinin bulunduğuna işaret etmektedir (Salnâme-i Vilâyet-i Bitlis, 1. Def'a, 1310: 199; Kara, 2019: 41). Her ne kadar haklarında tafsilatlı bilgiye sahip olmasak da, söz konusu imal faaliyetlerinin gerçekleştiği atölyelerin şehrin mimarisinde 
önemli bir unsur olduğu anlaşılmaktadır. Yine burada şehirdeki ticaret hayatını yansıtan dükkânlardan da söz etmek gerekir. Örneğin 1889 yılında Minare Mahallesi'nin Yukarı Çarşı kısmında bir han inşa edildiğini biliyoruz (Kulağuz, 1997: 82-84). Yoldüzler Hanı olarak bilinen söz konusu hanın, çarşıda bulunan başka dükkânlara ilave olarak yapıldığı anlaşılmaktadır. Nitekim Mayevsky'nin bölgeye ilişkin raporunda yer alan “...pazarında birçok dükkânlar vardır. Suret-i umumiyede o havalinin ticaret merkezidir." şeklindeki kısa değinisi de bu dönemde şehir çarşısının manzarasinı aksettirebilecek cinstendir (Mayevski, 2007: 403). Yine bu dönemlerde şehirde Yıldızlı Han ve Aslanlı Han gibi ticari yapıların inşa edildiği de anlaşılmaktadır (Muş Belediyesi Arşivi, 2020). ${ }^{8}$

19. yüzyılın sonu ile 20. yüzyıl başlarında birer tanesi Minare, Kale ve Süfela mahallerinde bulunan 10 ibtidâi, ${ }^{9}$ tamire muhtaç durumdaki 9 medrese, ${ }^{10} 27$ camii ve mescid, 2 minare, 5 hankâh, 1 kütüphane ve altının dükkân olduğu bildirilen iki katlı ve dört sinıflı 1 rüşdiye (Yıldız, 2019: 60, 61; Bingül, 2019b: 53, 56, 58) ile 1 mülki idadi mektebi ve 3 Ermeni mektebi (Muş Ermeni Katolik Mektebi, Muş Ermeni Protestan Erkek Mektebi ve Muş Ermeni Protestan Kız Mektebi) binalarına (Yıldız, 2019: 65. 68-69) ${ }^{11}$ ve 4 ya da 7 kiliseye (Lynch, 1971: 171) ilave olarak idare ve belediye meclisi, bidayet mahkemesi, hapishane (Bingül, 2019: $27,31),{ }^{12}$ banka, nüfus, vergi ve zaptiye dairelerinin yanı sıra bunlara bağlı bazı birimlerin de mevcut olduğu görülen Muş (Salnâme-i Vilâyet-i Bitlis, 1. Def'a, 1310: 195-199; Bingül, 2019: 21-22), hiç de gelecek vadeden bir şehir gibi görünmemektedir. Yine bu dönemde Ermeni terörü nedeniyle kötü günler geçirdiğini bildiğimiz şehrin, ${ }^{13}$ Osmanlı Devleti'nin içerisinde olduğu savaşlar nedeniyle de fazla gelişme kaydedemediği söylenebilir. Nitelim Muş’un 19. yüzyıldaki bu durumunun nüfus istatistiklerine yansıdığı da görülmektedir. 1830'lu yıllarda 7 bin civarında olduğu değerlendirilen Muş nüfusu, yüzyılın sonuna gelindiğinde iskân faaliyetlerinin de etkisiyle 27 bin dolaylarına çıkmış olsa da ${ }^{14} 1927$ yılında yapılan Cumhuriyet döneminin ilk nüfus sayımında bu rakam 21 binlere düşmüştür (Dölek, Avcı ve Harunoğulları, 2018: 1015). 19. yüzyılda Muş

\footnotetext{
${ }^{8}$ Muş Belediye Arşivi'nde bulunan evraka ulaşma noktasında desteklerini esirgemeyen Muş Alparslan Üniversitesi Rektörü Prof. Dr. Fethi Ahmet Polat'a, Muş Belediye Başkanı Feyat Asya'ya, Muş Belediye Başkan Yardımcısı Aydın Özarslan'a ve Belediye İmar İşleri çalışanı M. Berken Bahadır Hanımefendi'ye teşekkür ederim.

${ }^{9}$ Sözü edilen bu ibtidâi mekteplerinden Muş İbtidâi Mektebi, Minare Mahallesi İbtidâi Mektebi, Kale Mahallesi İbidâi Mektebi, Muş İnas İbtidâi Mektebi ve Süfla İbtidâi Mektebi ile alakalı olarak bkz. Yıldız, 2019: 54-56

${ }^{10}$ Şehir yıllı̆̆ , Cumhuriyet'ten önce Muş'ta Alaaddin Bey Medresesi ve Ulu Camii Medresesi olmak üzere iki medresenin faaliyet gösterdiğini kaydetmiştir. Bkz. 1967 Muş İl yıllığı, 1968: 73

11 1910'larda bu Ermeni okulları faaliyetlerini sürdürmekteydi. Protestan Alman misyonerlerin Kale mahallesindeki Hıristiyan okullarında öğretmenlik yapıp buradaki bir yetimhane ve hastaneyi işletiyorlardı. Bkz. Öney, 2019: 77. Richard G. Hovannisian, bu dönemde şehir çarşısında Ermenilere ait 800 dükkân ve atölye olduğunu kaynak göstermeden kaydetmiştir. Yine onun bildiğine göre, I. Dünya Savaşı'ndan önce şehirde faal olan beş Ermeni kilisesi ve bunlara ait okullar, İzmirliyan Kız Okulu ve bir de kolej bulunuyordu. Bkz. Hovannisian, 2016: 11.

${ }^{12}$ Sözü edilen hapishane ile alakalı müstakil bir çalışma için bkz. Tanış, 2018: 141-146.

${ }^{13}$ Genelde Muş Sancağı ve özel Muşşsehrindeki Ermeni faaliyetleri ile alakalı ayrıntılı bilgi için bkz. Darkot, 1979: 746; Tuncel, 2006: 370; Çabuk ve Tombul, 2019: 1-14.

${ }^{14}$ Muş ve çevresindeki iskân faaliyetlerine bir örnek olarak bkz. Öztürk ve Toprak, 2018: 437-458.
}

nüfusunun nasıl bir grafik izlediği çağdaş kayıtlar üzerinden takip edilebilmektedir. Buna göre, Brant 1838 yılında şehirde 700 Müslüman ve 500 Ermeni ailesinin olduğunu (Brant, 2014: 29); aynı yıl Muş'a gelen Horatio Southgate kalesi harap halde bulunan şehirde 600’ü Müslüman (aynı yazar Muş’taki Müslümanların kendilerine Osmanlı değil, Türk dediklerini belirtir) ve 300’ü Ermeni 900 ailenin bulunduğunu ve yaklaşık 5 bin kişinin yaşadığını (Southgate, 1840: 202-203); Koch 1846 yılında 1000 Müslüman ve 415 Ermeni ailesi olduğunu; Henry F. Tozer 1881 yılında 800'ü Ermenilere ait olan 3000 ev bulunduğunu (Tozer, 1881: 283); Lynch şehir nüfusunun 20 bini aşmadığını (Lynch, 1971: 172-173); Şemseddin Sami ve Vital Cuinet yüzyılın son on yılında şehirde 37 bin kişi olduğunu; Mayevski'nin 1899 tarihli raporu ise nüfusu 15-20 bin civarlarında olan Muş'ta bulunan 2700 evin 1500'ünün Müslümanlara ve 1200'ünün ise Ermenilere ait olduğunu belirtmiştir (Mayevski, 2007: 403). Aynı şekilde I. Dünya Savaşı'ndan hemen önce şehir nüfusunun 20 bin olduğunu kaydeden E. Banse'nin kaydını da burada not etmek gerekir (1967 Muş İl Yıllığg1, 1968: 27; Darkot, 1979: 746-747; Tuncel, 2006: 370).

1903 y1lındaki depremden (Tuncel, 2006: 370) etkilenen Muş'un özellikle mimarî yapılar düzleminde ne kadar hasar gördüğünü anlamak zordur. Mahallelerin birbirlerine çok yakın (Kara, 2019: 35) ve yer yer iç içe geçmiş olması dolayısıyla birçok evin yıkıldığını tahmin etmek mümkün olmakla birlikte, şehrin 19. yüzyıl sonlarındaki dokusunu koruduğu anlaşılmaktadır. Örneğin I. Dünya Savaşı öncesinde Muş'ta bulunan misyonerlerden kalmış bazı fotoğraflar (Öney, 2019: 80-81) ya da şehri ziyaret eden kimselerin bırakmış oldukları yazılı tasvirler bunu doğrulamaktadır. Öte yandan belirtmek gerekir ki, I. Dünya Savaşı yılları Muş için gerçek bir yıkım dönemi olmuştur. Ekonomik düzen bozulmuş, güvenlik sorunları baş göstermiş, nüfusun önemli bir bölümü göç ederek şehirden ayrılmıştır (Darkot, 1979: 747; Gök, 2019: 193; Kardaş, 2019: 117).

\section{Bir Cumhuriyet Şehri Olarak Muş}

I. Dünya Savaşı sıralarında Ruslar tarafından işgal edilen ve adeta bir harabe haline gelen Muş'un, Cumhuriyet döneminde yeni bir gelişme sürecine girdiğini biliyoruz (Abdurrahim Şerif, 2011: 432; Darkot, 1979: 747; Tuncel, 2006: 370). Önce il haline getirilmiş olsa da 30 Mayıs 1926'da Bitlis'e bağlanan ve 3 Haziran 1929'da yeniden ile dönüştürülen (Cumhurbaşkanlığı Cumhuriyet Arşivi (CCA), 3018-1-2-2-18-1) şehrin I. Dünya Savaşı sırasında aldığı yaraların da sarılması için yoğun çalışmalara başlanmıştı (1967 Muş İl Yıllığı, 1968: 15; Çağlayan, 2019: 123-124, 127). ${ }^{15}$ 1931 yılında bir ortaokulun açılmasının ve Bitlis'teki devlet hastanesinin nakledilmesinin planlandığı Muş’un (CCA, 30-10-0-0-178-226-7), beyaz badanalı gösterişsiz evlerin yamaçlarında bulunduğu kalenin merkezde yer aldığı eski şehirden ovaya doğru yayılım gösterdiği Cumhuriyet'in ilk yıllarında, 1938 yılında hemen önünde açılan Cumhuriyet Meydanı'nda bir Atatürk anıtının da yapıldığı (San, 1966: 200) Hükümet Konağ ${ }^{16}{ }^{16}$ Belediye ve Vali Konağı, Vilayet Jandarma Kumandanlığı, Atatürk İlkokulu, Muş Ortaokulu,

\footnotetext{
${ }^{15}$ Cumhuriyet'in ilk dönemlerinde Muş milletvekillerinin şehrin gelişmesine dönük çabaları ile ilgili olarak bkz. Özalper, 2015: 512-528.

${ }^{16} 1937$ yılında Mutki ve Tatvan hükümet konakları ile birlikte "emaneten" yapılması yönünde bir karar alınmıştı. Bkz. CCA, 30-18-1-2-80-93-10.
} 
günümüzde Muş Belediyesi'nin ek hizmet binası olarak kullandığ1 yerde olan ve binanın yapımı esnasında, daha sonra "okunmadan Diyarbakır müzesine" gönderildiği bilinen bir kitabenin bulunduğu bilinen Halkevi (1967 Muş İl Yıllığı, 1968: 39; Yuca, 2019: 36), Dispanser, Muayene ve Tedavi Evi, Belediye Parkı ile Futbol Sahas ${ }^{17}$ gibi yap1lar ve memurlar için İskandinav modeli lojmanların yapıldığı Kültür Mahallesi’nin kurulması ile yeni ve modern bir şehir haline getirilmeye çalışıldığını söyleyebiliriz (Çağlayan, 2019: 127-128). Yine bu dönemde şehirde bir kütüphanenin de bulunduğunu ve henüz kendi binası yapılmamış olan bu kütüphane için ana caddede bir binanın kiralandığını biliyoruz (1973 Muș İl Yıllığı, 1974: 72-73). Dönemin valisi Tevfik Sırrı Gür'ün önderlik ettiği 1930'lu yıllardaki bu dönüşüm sürecinde ayrıca şehre yeni nüfus unsurları da iskân edilmiş, bunların bir kısmına ev, arsa ya da para verilmiş ve bir kısmı için de evler inşa edilmişti (Çağlayan, 2019: 133).

1927 yılında gerçekleştirilen nüfus sayımına bakılırsa bu dönemde yalnızca 4227 kişinin yaşadığı görülen Muş'un nüfusu 1935 'te 5158,1940 'da 5681 ve 1945 'te 5040 olarak kaydedilmiştir (1967 Muş İl Yıllığı, 1968: 27). 1940’lı yılların ortalarından itibaren şehirdeki nüfus artışı ivme kazanmış (1967 Muş İl Yıllığı, 1968: 27; Dölek, Avcı ve Harunoğulları, 2018: 1015), 1950 yılında 7050 olduğu görülen Muş nüfusu sonraki yıllarda da periyodik olarak artmış olup 1950'li yılların başında şehirde 5 mahalle, 1200 ev, 3 han, 2 cami ve 2 hamam bulunduğu kayıt altına alınmıştır (1967 Muş İl Yıllığı, 1968: 27; Darkot, 1979: 747; Tuncel, 2006: 370). 1955 y1lında gerçekleştirilen nüfus sayımında 10888 ve 1960 'da 11965 olan, 1965 yılındaki sayımda 15687'ye çkan (https://biruni.tuik.gov.tr/nufus80app/idari.zul?yil=1965.) Muş nüfusu, 1966 yılında meydana gelmiş olup iki binden fazla insanın ölümüne neden olan Varto depremlerinden (Yurt Ansiklopedisi, VIII, 1982-1983: 5983) sonra buradan şehre getirilenlerin de katılmasıyla 1970 yılında 23058 ulaşmış

(https://biruni.tuik.gov.tr/nufus80app/idari.zul?yil=1970),

rakam 1975 'te 27761

(https://biruni.tuik.gov.tr/nufus80app/idari.zul?yil=1975), 1980'de 40977

(https://biruni.tuik.gov.tr/nufus80app/idari.zul), 1985'te 42159 (https://biruni.tuik.gov.tr/nufus85app/idari.zul),

1990'da 44019

(https://biruni.tuik.gov.tr/nufus90app/idari.zul) ve 2000'de ise $67927 \quad$ olmuştur (https://biruni.tuik.gov.tr/nufusapp/idari.zul). Adrese dayalı nüfus verilerinden elde edilen istatistiklerini TÜİK veri tabanlarından elde edebildiğimiz 2007 yılından itibaren ise küçük çaplı dalgalanmalar bir yana bırakılacak olursa nüfus düzenli bir biçimde artış kaydetmiştir. Buna göre, Muş'un nüfusu 2007'de 70509, 2008'de, 69507, 2009'da 72774, 2010'da 74902, 2011'de 81918, 2012'de 81764, 2013'te 84121,2014 'te 88409,2015 'te 91126,2016 'da 93052, 2017'de 95717, 2018'de 107470 ve 2019'da 111927 rakamlarını

görmüştür

\footnotetext{
${ }^{17} 1967$ İl Yıllığı’nda Vali Tevfik Gür döneminde “şimdiki lise binasının olduğu yerde" yaptırılan futbol sahasının "bu değerli insanın" şehirden ayrılmasından sonra bakımsız kaldığını ve șehirde hâlihazırda spor ile alakalı herhangi bir kurum ve kuruluş olmadığı not edilmiştir. "İlimizde şimdiye kadar herhangi bir spor tesisi yoktur.” Bkz. 1967 Muş İl yıllığı, 1968: 95-96.
}

(https://biruni.tuik.gov.tr/medas/?kn=95\&locale=tr). Cumhuriyet'in ilk dönemlerinden bugüne kadar geçen neredeyse bir asırlık süreçte Muş şehrinin nüfusunun sistematik bir biçimde artmış olmasının, şehrin kentsel gelişiminin izlerini takip edebileceğimiz verimli bir zemin olduğunu söylemek hata olmaz. Nitekim şehir nüfusunda kaydedilen artışlar, aynı zamanda Muş’ta gerçekleşen imar ve inşa faaliyetlerine ilave olarak eğitim, sağlık ve sanayi alanında yaşanan gelişmelerin etkilerini de yansıtan önemli göstergelerdir.

1930’lu yillarda ivme kazanan modern bir Cumhuriyet şehri inşa etme gayretleri daha sonra da hız kesmeden devam etmiştir. Bu çerçevede bölgenin tarım potansiyelini geliştirmek adına, 1930'lu yıllar Türkiye'sinin önemli bir kurumu olan Zirai Kombinalar İdaresi tarafindan 1949 yılında şehir merkezine $8 \mathrm{~km}$ mesafede ve 7200 hektarlık bir alan üzerinde Alparslan Devlet Üretme Çiftliği kurulmuştur (1967 Muş İl Yıllığı, 1968: 129; 1989 Muş İl Yıllı̆̆ı, 1989: 26; Atl1, 2019: 368). Daha sonraları Devlet Üretme Çiftliği'ne devredilecek olan bu kurumun Muş ekonomisi açısından uzun yıllar önemli bir rol üstleneceğini belirtelim. Demokrat Parti'nin iktidara geldiği 1950 yılında sonra gelişme hızının katlandığı görülen Muş’un çehresi hızla değişmeye başlamıştır. Öncelikli olarak Muş'un komşu illerle irtibatını kuran karayollarının ve su şebekesinin yenilendiği bu dönemde faaliyete geçmiş olup 1972 yılında yapımı tamamlanacak olan hatlarla şehri İran'a bağlayacak olan demiryolu hattı, Muş tarihinde bir dönüm noktası olmuştur (1967 Muş İl Y1llığı, 1968: 27; A. Kardaş, 2019: 2375; Atlı, 2019: 363; Ersungur ve Aslan, 2014: 222). ${ }^{18}$ Açılışını Başvekil Adnan Menderes'in yaptığı demiryolu hattının faaliyete geçmesinden sonra şehir istasyon yönünde hızlı bir genişleme dönemine girmiştir (CCA, 30-1-0-0-134-874-2). Nitekim aynı yıl kurulan Muş Yapı Kooperatifi'nin faaliyetlere başlaması da şehirde yeni dönemde yapılacak imar faaliyetlerinin bir habercisi gibidir (CCA, 30-18-1-2-140-68-15). Demiryolunun faaliyete geçmesinden hemen sonra, halk evlerini istasyona yakın mahallerde inşa etmeye başlamıştır (1973 Muş İl Yıllığı, 1973: 7). 1920-1950 yılları arasında şehre yapılan bayındırlık yatırımlarının bölge illeri ortalamasının (Kopar, 2009: 200) ve 1946-1960 yılları arasındaki dönemde genel iller ortalamasının üzerinde olması, Muş'un bu dönemlerde kaydettiği gelişmeyi göz önüne sermesi bakımından dikkate değerdir (Aşgın, 2000: 239).

1956 yılında şehirde ilk matbaanın kurulmasıyla basın yayın faaliyetlerinin de başladığını bildiğimiz Muş'un kentsel gelişiminde eğitim kurumlarının önemli yeri vardır. 1960'lı yılların ikinci yarısında 7 ilkokulun bulunduğu şehir merkezinde ayrıca 1 ortaokul, 1945'te kurulmuş olup henüz kendisine ait bir binası bulunmayan Muş Merkez Akşam Kız Sanat Okulu, 1955'te kurulan ve yüz kişilik bir pansiyonu da olan Muş Lisesi, 1959'da kurulan ve muhtelif zanaat alanlarında eğitim veren Sanat Enstitüsü, 1963'te kurulan Kız Enstitüsü, 1964 yılında şehir merkezine 4 km mesafede kurulan Merkez Yatılı Bölge Okulu, 1966'da kurulmuş olan Ziraat Lisesi ve İmam Hatip Okulu ile 1969'da kurulan Kız Öğretmen Okulu, 1962-63 eğitim öğretim dönemde Köy Ebe Okulu adıyla açılmış olup 196667 döneminde kendi bina-sına taşınan Sağlık Okulu, 1968 yılında eski lise binasının yeniden yapılandırılarak Yatılı Bölge Okulu'nun buraya taşınmasıyla oluşturulan ve özel-

\footnotetext{
${ }^{18}$ Muş demiryolu hattının inşa süreci ile alakalı detaylı bilgi için bkz. Kaynar, 2019: 395-409.
} 
likle Varto depreminde kimsesiz kalan çocukların yerleştirildiği Merkez Yetiştirme Yurdu ve bir halk kütüphanesi olup bu dönemde bir yerel gazetesi, bir dergisi ve iki kışlık sineması ile Muş kültürel bakımdan vasat bir görüntü arz etmekteydi (1967 Muş İl Yıllığ1, 1968: 74, 78, 86-87, 90; 1973 Muş İl Yıllığı, 1973: 61-64, 66; 1989 Muş İl Yıllığı, 1989: 45). Bu türden imar faaliyetleri daha sonra da devam etmiştir. 1973 yılında şehir merkezinde 8 ilkokul, 1 Lise, 1 Sanat Enstitüsü, 1 İmam Hatip Okulu, 1 Kız Öğretmen Okulu, 1 Ziraat Lisesi ve 1 Sağlık Okulu'na ilave olarak 3 sinema vardır (1973 Muş İl Yıllığı, 1973: 20, 61, 100). 1979-80 eğitim öğretim döneminde Sağlık Koleji adı ile dört yıllık bir okula dönüştürülen Sağlık Okulu, 1982-83 döneminde Sağlık Meslek Lisesi yapılarak faaliyetlerini sürdürmüştür (1973 Muş İl Yıllığı, 1973: 54, 56; 1989 Muş İl Yıllığı, 1989: 45; Atlı, 2019: 363). 1980'li yılların sonunda Muş'ta faaliyet göstermekte oldukları görülen 30 ilkokul, 9 ortaokul, 3 Lise, 1 Endüstri Meslek Lisesi, 1 Teknik Lise, $1 \mathrm{~K}$ ız Meslek Lisesi ve 1 Uygulamalı Kız Sanat Okulu (1989 Muş İl Yıllığı, 1989: 49, 51), şehrin nüfusundaki artışa paralel olarak kamusal nitelikli yapıların sayısının da arttığını göstermektedir. Nitekim bu çerçevede yine 1987 yılında Alparslan Çiftliği’nde kurulan Fırat Üniversitesi Muş Meslek Yüksekokulu'nu da burada zikretmek gerekir (1989 Muş İl Yıllığı, 1989: 51). Bu bahiste şehir kütüphanesine de ayrıca temas etmek yerinde olacaktır. 1932 yılından beri faaliyet içerisinde olduğunu bildiğimiz şehirdeki kütüphane, 1970 yılına kadar kiralık bir binada hizmet vermiş, bu yıl İstasyon Caddesi üzerinde ve Devlet Hastanesi'nin karşısında inşası tamamlanan üç katlı kendi binasına taşınmıştır (1973 Muş İl Yı1lı̆̆g, 1973: 72-73).

Muş'un kentsel gelişiminde önemli bir yere sahip olan 1960’lı yıllar, şehirdeki kamu yatırımlarının da daha önce hiç olmadığı kadar arttığı bir dönem olmuştur. Bu çerçevede 1963 yılında Alparslan Devlet Üretme Çiftliği arazisinde Ziraat İşleri Genel Müdürlüğüne bağlı Deneme ve Üretme İstasyonu ile Muş Çayır Mera Yem Bitkileri ve Zooteknik Araştırma Enstitüsü, 1964 yılında Zirai Donatım Kurumu Bölge Müdürlüğü ve Toprak Su Ekip Başmühendisliği kurulmuş ve bu şekilde şehrin tarım ve hayvancılık potansiyelinden azami ölçüde istifade edilebilmesinin yolları aranmıştır (1967 Muş İl Yıllı̆̆ı, 1968: 134, 150; 1973 Muş İl Yıllığı, 1973: 146; 1989 Muş İl Yıllı̆̆ı, 1989: 32; Atlı, 2019: 363, 367-368, 370). ${ }^{19} \mathrm{Bu}$ çerçevede 1967 yılında Muş Belediyesi tarafından bugün Eski Çarşı olarak bilinen mıntıkada yaptırılmış olup 400 metrekarelik bir alan üzerine kurulan 76 dükkândan oluşan ve şehrin tarımsal üretimindeki artışı aksettiren hal binası da zikredilmelidir (1967 Muş İl Yıllığı, 1968: 191). Yine 60’lı yıllarda şehirde Teknik Ziraat Müdürlüğü, Veteriner Müdürlüğü ve Meteoroloji Müdürlüğü gibi kamusal kuruluşların olduğunu da belirtemeden geçmemek gerekir (1967 Muş İl Yıllığı, 1968: 119 vd.). 1930'lu yıllarda Vali Tevfik Sırrı Gür tarafindan lise binasının bulunduğu yerde yaptırılmış olan spor sahası 1963 yılında yıktırılmış ve yeni bir stadyum inşası yönünde çalışmalar başlatılmıştır. Bu çerçevede 1968 yılında Vali Vefik Kitapçıgil tarafindan şehirde atçılık sporunu geliştirmek için bir koşu sahası ve tribüne ilave olarak bir kayak evinin yaptırıldığını, ayrıca 1970 yılında Muş Stadyumu'nun inşasına başlandığı ve 1974 yılında 1500 kişi kapa-

\footnotetext{
${ }^{19}$ Şehirde gerçekleştirilen tarımsal etkinliklerle ilgili olarak bkz. Sönmez, 2005: 59-82.
}

siteli açık tribünlü stadyum inşaatının tamamlandığını söyleyelim (1973 Muş İl Yıllığı, 1973: 106; 1989 Muş İl Yıllığ1, 1989: 57).

Varto depreminin Muş'un kentsel gelişiminde büyük etkisi olduğunu biliyoruz. 1966 yılının Ağustos ayında vuku bulan deprem felaketinin ardından Varto'ya bağlı köylerin bir kısmı boşaltılarak burada yaşamakta olan nüfus şehrin merkezine iskân edilmiştir. Bu çerçevede toplamda 11223 adet ahşap baraka, nüve konut, prefabrik barınak ve ahırın yapıldığı bu yıllarda şehir oldukça kalabalıklaşmıştır. Kapsamlı imar hedeflerinin bir kısmının akamete uğradığını da bildiğimiz bu yenide dönemde, nüfus istatistiklerine de açık bir biçimde yansıdığı gibi şehrin kentsel gelişimi büyük bir ivme kazanmıştır. İstasyon Caddesi'nin sağ yanında inşa edilen ve Sunay mahallesini meydana getiren betonarme konutlara veya yolun öbür tarafindaki baraka tipi evlerden teşekkül eden Zafer mahallesine yerleştirilen Vartolular yalnızca şehrin nüfusunu arttırmakla kalmamış, süreç aynı zamanda Muş'ta yeni iş alanlarının ortaya çıkmasına da zemin hazırlamıştır. Muşlular, yeni teşekkül eden mahallelerde inşa edilen binalarda usta ve işçi olarak çalışmaya başlamış, bu durum doğal olarak şehrin ekonomisine de hareketlilik getirmiştir. 1966 yılına kadar Hükümet Konağ çevresinde öbeklenen şehir, bu tarihten itibaren hızla istasyona doğru genişlemeye başlamıştır (1967 Muş İl Yıllığı, 1968: 27, 182; 1973 Muş İl Yıllığı, 1973: 19, 26). Nitekim bunu doğrulayan bir veri olarak 1967 yılında İstasyon Caddesi üzerinde İl Özel İdaresi tarafindan yaptırılan 22 dükkân ve "oldukça kon-forlu turistik otel"i zikredebiliriz (1967 Muş İl Yıllığı, 1968: 190). Şehir merkezinin İstasyon tarafina doğru genişlemesi yönündeki eğilimin resmî makamlar tarafindan da güçlü bir biçimde desteklendiğini belirtelim. Örneğin 20 Nisan 1967'de Dere Mahallesi’nde meydana gelen yer kayması nedeniyle bir evin yıkılması üzerine durumları tehlikeli görülen 85 konut tahliye edilmiş ve burada yaşamakta olan aileler, İstasyon yakınlarındaki boş barakalara yerleştirilmiştir. Yine afetten etkilenen 191 aile için şehir merkezinde konut inşasına başlandığını da biliyoruz (CCA, 30-1-0-0-73-464-3). Nitekim bir süre sonra bu civardaki yerleşimler kanıksanmış ve 1972'de İmar ve İskân Bakanlığı tarafindan alınan karar doğrultusunda deprem nedeniyle şehir merkezinde oluşturulan geçici iskân alanlarının kalıcılaştırılması yönünde irade oluşturulmuştur (1973 Muş İl Yıllığı, 1973: 19).

Muş'un kentsel gelişim tarihinin bir diğer önemli hattı sağlık kuruluşlarıdır. Cumhuriyet döneminin ilk yıllarında Özel İdare tarafindan Kale Mahallesi'nde kurulduğu ve kiralık bir bina içerisinde hizmet verdiği bilinen sağlık evi, 1930'lu yılların sonunda 4-5 yataklı bir dispansere dönüştürülmüş, buranın yetersiz kalması üzerine 15 yataklı yeni bir dispanser daha yapılmıştır. 1940'lı yılların sonunda 25 yataklı bir hastaneye dönüştürülen ve "Memleket Hastanesi" adıyla bilinen bu sağlık kuruluşu, 1954 yılında "Devlet Hastanesi" adını almıştır. 1956 yılında 50 yatak kapasiteli yeni binasında hizmet vermeye başlayan Devlet Hastanesi'ne 1963 yılında ek bir bina yapılmış ve yatak kapasitesi 100’e çıkarılmıştır (1989 Muş İl Yıllığı, 1989: 43-44). 1960'lı yılların ikinci yarısına gelindiği vakit şehir merkezinde 2 sağlık ocağı, 1963 yılında uygulamaya konulan Muş İli'nin Sosyalizasyonu projesi çerçevesinde 100 yatak1ı bir ek blok ilave edilerek büyütülen 150 yataklı devlet hastanesi ve muhtelif alanlarda sağlık hizmeti veren çeşitli birimler (Verem Savaş Başkanlığı, Nüfus Planlama Başkan- 
lığı vb.) olduğu görülmektedir (1967 Muş İl Yıllığı, 1968: 102-104). 1969'de Gögüs Hastalıklar Hastanesi adıyla yapımına başlanmış olup 1987 'de tamamlanabilen 150 yataklık yeni blok ile hasta barındırma kapasitesi 300'e çıkan Devlet Hastanesi, aynı yıl 30 yataklı Hasköy Entegre Birimi ve 150 yatak kapasitesine sahip yeni entegre birim olan Kadın ve Çocuk Hastalıkları bölümünün de ilave edilmesiyle 480 yatak kapasitesine yükselmiştir. 2005'te yeni bir yapılanmaya gidilip Devlet Hastanesi ile Hasköy Entegre Birimi ve Kadın ve Çocuk Hastalıkları Hastanesi ayrılmış, 2011 yılında Sağlık Bakanlığı'nın kararı doğrultusunda Muş Devlet Hastanesi ile Kadın ve Çocuk Hastalıkları Hastanesi Muş Devlet Hastanesi çatısı altında birleştirilmiştir. 2010'lu yılların sonunda 434 fiili yatak kapasitesine ulaşan ve kalp ameliyatlarının yapılabildiği Muş Devlet Hastanesi, TOKİ tarafindan Bitlis yolu üzerinde yapılmış olan modern tesislerinde hizmet vermeye devam etmektedir (https://musdh.saglik.gov.tr/TR,240542/hastanemizhakkinda.html).

1967 tarihli şehir yıllığında "Endüstri yoktur" (1967 Muş İl Yıllığı, 1968: 53) cümlesiyle özetlenen Muş şehrinin sanayisi 1970'li yıllardan sonra biraz yavaş da olsa gelişme kaydetmeye başlamıştır. 1968'deki bir kararla 'Kalkınmada Öncelikli İller" kategorisine alınan Muş'taki ilk önemli sanayi tesisinin 1974 tarihinde kurulan Muş Süt Fabrikası olduğunu biliyoruz (1989 Muş İl Yıllığı, 1989: 25-26). 1976'da Muş Organize Sanayi Bölgesi'nin kurulması yönünde resmî bir karar alınmış olmakla birlikte (CCA, 3018-1-2-364-2-17), 2000'li yıllarda faaliyete geçeceğini bildiğimiz bu tesisin kuruluşunun karar aşamasında kaldığ anlaşılmaktadır. Yine 1970'li yıllarda bir kısmı akamete uğramış olmakla birlikte şehirde Muş Et ve Balık Kombinası, Muş Meyan Kökü Fabrikası ve Muş Gıda Ürünleri Sanayii gibi tesislerin oluşturulması yönünde adımlar atılmış olup bu girişimleri başkaları takip etmiş (Arslan, 2018: 78) ve 1980'li y1llar Muş sanayisinin önemli gelişmeler kaydettiği bir dönem olmuştur. Bu çerçevede 1976-1980 yılları arasında inşa edilen (Yalçın, 2009: 423), Muş'un en büyük sanayi tesisi olarak 1983'te Bitlis yolu üzerinde Muş Şeker Fabrikası (Yurt Ansiklopedisi, VIII, s. 6015; Muş (Merkez) İlave+Revizyon İmar Planı Plan Araştırma Raporu, 79), 1984'te Peynir ve Tereyağı Fabrikası, 1985 'te Özel İdare Yem Fabrikası'na ilave olarak yine bu dönemde Barit $^{20}$ ve Tütün Yaprak fabrikaları, 1990'da BAL-TAT Şeker, Muş Plastik ve Aytunçlar PVC fabrikaları ile 1998'de Yazıcıoğlu Yem Fabrikası (Muş (Merkez) İlave+Revizyon İmar Planı Plan Araştırma Raporu, 79-81) kurulmuştur (1989 Muş İl Yıllığı, 1989: 21-23, 26; Tuncel, 2006: 370; Arslan, 2019: 79).

1960'lı yılların sonunda belli başlı caddesi tren garından yukarı doğru Cumhuriyet Meydanı ve Hükümet Konağı'na uzanan İstasyon Caddesi olan (1967 Muş İl Yıllığı, 1968: 179) Muş, yirmi yıl içerisinde yeni bir çehre edilmeye ve 1980’lerin sonunda küçük bir kasaba görünümünden çıkarak bambaşka bir biçime kavuşmaya başlamıştır. Nitekim İller Bankası tarafından yapılan 1985 tarihli Muş İmar Planı'na bakıldığında, şehirdeki yerleşim alanlarının yoğunlaşmaya başladığı, bugün Sunay ve Yeşilyurt mahallelerini ayıran ve Bitlis'e giden D300 karayolunun hemen hemen

\footnotetext{
${ }^{20}$ Muş Belediyesi raporlarına bakılırsa, merkez ilçe alanı içerisinde 3235 bin ton barit rezervine sahip yataklar bulunmaktadır. Bkz. Muș (Merkez) İlave+Revizyon İmar Planı Plan Araştırma Raporu, 52.
}

Muş Sanayi Sitesi'ne kadar olan kısmının iki taraflı olarak yerleşime açıldığı görülmektedir (Muş 1985 Tarihli İmar Planı, Muş Belediyesi Arşivi). Dolayısıyla söz konusu imar planından hareketle, şehrin fiziksel gelişiminin 1980'li yıllarda doğu istikametinde yoğunlaştı̆̆ 1 söylenebilir. $\mathrm{Bu}$ yıllarda Muş'un sergilediği fiziksel gelişmenin etkileri başka alanlarda da görülmeye başlanmıştır. Nitekim 1922 yılında şehirde Fırat Üniversitesi'ne bağlı Eğitim Fakültesi'nin kurulması ya da 1996 yılında Van Yüzüncü Yıı Üniversitesi'nin çatısı altında bir Sağlık Meslek Yüksekokulu'nun ve Alparslan Devlet İşletme Çiftliği arazisinde bir KYK Öğrenci Yurdu'nun faaliyete başlaması bu zaviye içerisinde ele alınabilecek gelişmeler cümlesindendir (Polat, 2019: 4). Bu bahis içerisinde son olarak havalimanını da zikretmek gerekir. Daha önce NATO Askerî Havalimanı olarak işlev görmekle birlikte 1992 yılında halkın kullanımina açılan ve şehir merkezine 18 kilometre mesafede bulunan (bu mesafe, havalimanının şehrin ana büyüme hattında bulunması dolayısıyla her geçe gün azalmaktadır) Muş Sultan Alparslan Havalimanı, iç hatları kullanan yolcu sayısı periyodik olarak artmaktadır (Muş (Merkez) İlave+Revizyon İmar Planı Plan Araştırma Raporu, 16; Arslan ve Kendir, 2019: 1968-169; Sönmez, 2005: 87). Daha önce Muş Havalimanı olan ismi 2018 yılında Muş Sultan Alparslan Havalimanı olarak değiştirilen (https://www.bik.gov.tr/mus-havalimaninin-adi-degisti/) havalimanının şehrin gelişim tarihinde önemli bir yeri olduğunu belirtelim.

\section{2000'li Yıllarda Muş}

2000'li yıllar, Muş'un kentsel gelişim tarihinde önemli bir yere tekabül etmektedir. Bu dönemde şehrin kentsel dönüşüm katsayısını hareketlendiren en önemli unsurun Muş Alparslan Üniversitesi olduğunu söylemek mümkündür. 1990'l1 yıllardan itibaren şehirde faaliyet göstermekte olan Fırat Üniversitesi Muş Eğitim Fakültesi ile Yüzüncü Yıl Üniversitesi Sağlık Meslek Yüksekokulu'nun çekirdeğini teşkil ettiği Muş Alparslan Üniversitesi 2007 yılında kurulmuştur. Eğitim Fakültesi, Sağlık Yüksekokulu, Sosyal Bilimler Meslek Yüksekokulu ve Teknik Bilimler Meslek Yüksekokulu olmak üzere dört akademik birim ile eğitimöğretim faaliyetlerine başlayan Muş Alparslan Üniversitesi, 2008'den 2015 yılına kadarki kuruluş sürecinde FenEdebiyat Fakültesi, İktisadi ve İdari Bilimler Fakültesi, İletişim Fakültesi, Mühendislik-Mimarlık Fakültesi, İslami İlimler Fakültesi ve Malazgirt Meslek Yüksekokulu olmak üzere altı akademik birim halinde yapılanmıştır. Yine bu dönemde Sosyal Bilimler ve Fen Bilimleri enstitüleri de kurulmuş, üniversitenin gelişmesi daha sonra da devam etmiştir. Bu çerçevede 2016'da Beden Eğitimi ve Spor Yüksekokulu, 2017'de Ziraat Fakültesi diploması veren Uygulamalı Bilimler Fakültesi, 2019'da Sağlık Bilimleri Fakültesi ve 2020'de Spor Bilimleri Fakültesi açılmıştır. 2018 yılında Bölgesel Kalkınma Odaklı Misyon Farklılaşması bağlamında hayvancılık alanında ve Yükseköğretimde Dijital Dönüşüm Çalışmaları kapsamında pilot devlet üniversiteleri arasına girmiştir (Polat, 2019: 4, 23; http://www.alparslan.edu.tr/sayfa.xhtml?sayfa=tarihce).

Kurulduğu 2007 yılından itibaren ikisi şehir merkezinde ve biri Muş-Bingöl yolu üzerindeki Karaköprü mevkiinde olmak üzere üç yerleşkede faaliyet gösteren Muş Alparslan Üniversitesi, 2012-2013 eğitim öğretim y1lında şehrin güneybatısında, Kulp yolunun üzerinde bulunan Güzeltepe 
mevkiindeki ana yerleşkesine taşınmıştır. Bilimsel araştırmaların halk tarafindan büyük oranda benimsenmiş olduğuna işaret ettiğ ${ }^{21}$ üniversitenin Muş'un gelişimi noktasında ürettiği katma değer yüksek seviyededir. 2020'de 10 bin civarında öğrencisi ile faaliyet göstermeye devam eden Muş Alparslan Üniversitesi, şehirde birçok alanda gelişme yaşanmasında etkili olmuş ve olmaya devam etmektedir. Öğrencileri, öğretim elemanları ve diğer personelleri ile birlikte 11 bine yaklaşan nüfus temsili ile şehrin genel nüfus oranının neredeyse onda biri gibi yüksek bir oranına karşılık gelen üniversitenin Muş’a sağladığı ekonomik değer, başta hizmet, konut ve konaklama sektörleri olmak üzere birçok alanda şehri dönüştürmüştür. ${ }^{22}$

2000'li yillarda Muş'un kentsel gelişimini tetikleyen tek unsur üniversite değildir. Şehir merkezinde, Saray Mahallesi'nde olan ve içerisinde 91 işyeri bulunan Muş Sanayi Sitesi'ne (Muş (Merkez) İlave+Revizyon İmar Planı Plan Araştırma Raporu, 76) ilave olarak 2000 yılında Lale Kuruyemiş Fabrikası kurulmuş (Muş (Merkez) İlave+Revizyon İmar Planı Plan Araştırma Raporu, 80), 2008'de şehir merkezine 27 kilometre mesafede bulunan ve 56 parselden oluşan Muş Organize Sanayi Bölgesi (MOSB) (Muş (Merkez) İlave+Revizyon İmar Planı Plan Araştırma Raporu, 78) faaliyete başlamış, 2008'de ÜÇKA Şeker Fabrikası (Muş (Merkez) İlave+Revizyon İmar Planı Plan Araştırma Raporu, 80), 2009'da hâlihazırda şehrin en büyük özel sanayi teşebbüsü olan Çimento Fabrikası açılmıș ve Muş'a $12 \mathrm{~km}$ mesafede bulunan Sungu beldesinde Tekstil Kent üretim sürecine girmiştir (Arslan, 2018: 79-80). Şehir halkı için önemli bir istihdam kaynağı olan söz konusu sanayi tesislerinin, Muş'un kentsel gelişimi açısından büyük bir kıymeti hâiz oldukları açıktır. Bu çerçevede 2009'da Karayolları Kavşağı'nda dikilen Sultan Alparslan heykelinin doğrudan kentsel gelişim faktörü olmasa bile kentsel gelişim göstergesi olarak zikredilmeye değer olduğu da söylenebilir (http://www.mus.gen.tr/haber-8994-mus-kavsagasultan-alparslan-heykeli-dikildi-haberi.html).

Son çeyrek yüzyılda şehrin fiziksel görünümünü ve kentsel gelişimini tayin eden unsurlardan biri de imar faaliyetleridir. Belediye, TOKİ ve İl Özel İdaresi tarafindan yaptırılan tesis ve binalar Muş'un çehresini değiştirmiş ve değiştirmeye devam etmektedir. 2009 yllında Kültür Mahallesi'nde 80 konut, 2010 yllında 300 yataklı ve 400 yatak kapasiteli Devlet Hastanesi, 2014 yilında Kale Mahallesi'nde kentsel dönüşüm kapsamında 715 konut, bir camii ve 115 dükkân, 2015 yılında Muş İl Emniyet Müdürlüğü binası, 2017 yılında Kepenek Mahallesi'nde 381 konut, 1 camii ve ticaret üniteleri ile 2019 yllında Muş Millet Bahçesi ve projeye ait sosyal donatıların inşa faaliyetlerine başlayan TOKI'nin söz konusu projelerinin neredeyse tamam 2020 yllında tamamlanmış durumdadır (https://www.toki.gov.tr/illere-goreprojeler). İl Özel İdaresi'nin 2006 ile 2019 yılları arasında Muş genelinde yaptırdığ 256 projenin 50'den fazlası şehir merkezinde olup bunlar arasinda okullar, idare binaları, sağlık tesisleri, lojmanlar vb. birçok kamusal donatı bulunmaktadır (Muş İl Özel İdaresi Arşivi). ${ }^{23}$ Yine Muş Belediyesi tarafindan yaptırılarak hizmete açılan Yeni Hal, Canlı Hayvan Pazarı ve Muş Şehirlerarası Otobüs Terminali

\footnotetext{
${ }^{21}$ Şehir halkının Muş Alparslan Üniversitesi'ne yaklaşımını ele alan bir çalışma için bkz. Çiçę ve Almalı, 2019: 90-111.

${ }_{22}$ Muş Alparslan Üniversitesi'nin şehre sağladığı ekonomik katkı ile alakalı olarak bkz. Çayın ve Özer, 2015: 131-147.

${ }^{23}$ İstatistikler için İl Özel İdare'den İbrahim Avcı'ya teşekkür ederim.
}

(MUŞTi) ya da başta Lale Parkı olmak üzere birçok sosyal tesisi de bu zaviye içerisinde zikretmek gerekir. Belediyesi 1923 yılında kurulmasına rağmen ilk imar planının 1985'te, bütününe ilişkin ilk çevre düzenleme planının ise 2008'de yapıldığı Muş’un (Muş (Merkez) İlave+Revizyon İmar Planı Plan Araştırma Raporu, 128) 2000'li yıllarda daha programlı bir belediyecilik anlayışına kavuş̧tuğu söylenebilir. Belediye Arşivi'nden elde etmiş olduğumuz biri 2012 ve ikisi 2013 yıllarına ait olan üç farklı imar planı, Muş'un gösterdiği gelişmeyi de yansıtması bakımından dikkat çekicidir. Şehrin 2000'li ylllarda ivme kazanan kentsel gelişim hızı, şehirdeki imar ve inşa faaliyetleri ile ilgili daha sık planlama yapılması gereksinimini ortaya çıkarmaktadır.

\section{Sonuç: Muş'un Bugünü ve Yarını}

Merkezini bugün Kale Parkı olan tepenin yamaçlarında ve aşağı kısımlarında bulunan, 2014'de başlanan kentsel dönüşüm bağlamında önemli bir kısmı maalesef yıkılan tarihî nitelikli bölgenin oluşturduğu Muş'un sözü edilen bölümünde Kale, 1930-1960 yılları arasında kurulan Muratpaşa ve Minare ile Dere adlarını taşıyan şehrin en eski mahalleleri bulunmaktadır. Zaman içerisinde ovaya doğru yayılarak $2.5 \mathrm{~km}$ uzaklıktaki İstasyon ve Sütlüce Köyü ile birleşen şehrin tarihî nitelikli kamusal yapılarının hemen tamamının yer aldığı bu bölgede bulunan dar ve dolambaçlı sokaklardan oluşan "Eski Şehir" tarihî hüviyetini büyük ölçüde yitirmiş durumdadır. Önümüzdeki dönemlerde uygulanması düşünülen yeni kentsel dönüşüm planlarının Muş’u büsbütün "yeni bir şehir" haline getireceği anlaşılmaktadır. Aynı zamanda şehrin en yüksek bölümünü de meydana getiren bu bölge, şehrin kendisinden başlayarak ovaya doğru genişleme kaydettiği bölgedir. Muş şehri kale bölgesinden kuzeydoğu, doğu ve kuzey yönünden alçalarak genişlemiş̧tir. 1950'lerin başında 1200 konutun yer aldığı beş mahalleden (beşincisi Cumhuriyet'in ilk yllarında kurulan ve Dere Mahallesi ile Atatürk Bulvarı arasında kalıp Elit Restoran'a kadar inen Kültür Mahallesi'dir) meydana gelen şehir (Tuncel, 2006: 370), 1955'te demiryolunun şehre gelișini takip eden süreçte hızla büyümeye başlamış ve 1966 'da gerçekleşen Varto depreminden sonra sözü edilen bu büyüme katlanarak hız kazanmıştır. Bu yıllarda kurulan ve Muratpaşa Mahallesi'nden Atatürk Çocuk Parkı'na dek uzanan Hürriyet Mahallesi ile Sunay ve Zafer mahallelerini başka mahalleler takip etmiş, 1990'lı y1llarda İstasyon ve Muş Sanayi Sitesi arasındaki üçgene yayılan Yeşilyurt ve Dere Mahallesi'nden başlayıp Cumhuriyet Caddesi boyunca Bitlis yoluna dek uzanan ve Muş Sanayi Sitesi'ne kadar uzanan alanı içerisine alan Saray mahalleleri kurulmuştur (Muş (Merkez) İlave+Revizyon İmar Planı Plan Araştırma Raporu, 20; Tuncel, 2006: 370).

Günümüzde Muş ilk merkezinin kuşbakışı haritasına bakıldığında Belediye'den tren garına kadar uzanan ve artık Karayolları Kavşağı'ndan yukarısı Atatürk Bulvarı olarak bilinen İstasyon Caddesi ile bu büyük caddeye paralel olan Cumhuriyet Caddesi adlı iki büyük caddeden ve bunların etrafinda gelişen mahallelerden oluştuğu görülmektedir. 2005 yllında yaklaşık 1100 hektarlık bir alan üzerine yayılan şehirdeki mahalle sayısı on iken (Tuncel, 2006: 370), 2016 yllına gelindiğinde bu sayı on dörde çıkmıştır. 30'un üzerinde caminin bulunduğu şehir merkezinde yer alan söz konusu mahalleler, yukarıda zikredilenlere ilave olarak Erzurum Caddesi'nin güneybatısında ve ova içerisinde bulunan Bağlar Mahallesi ile 2016 yllında kurulan Yeni 
Mahalle, Karşıyaka ve 15 Temmuz Milli İrade mahalleleridir. Şehir merkezinde faaliyet halinde olan 44 resmî kurum ve kuruluşun idari tesisleri Kültür, Sunay ve Minare mahallelerinde yoğunlaşmıştır (Muş (Merkez) İlave+Revizyon İmar Planı Plan Araştırma Raporu, 82-83). Ek olarak şehir merkezinde 132'si konaklama ve eğlence birimi olan 1293 ticari işletme, 2'si özel sektöre ait olan sağlık merkezinin yanında 6 Sağlık Ocağı, 1 Devlet Hastanesi, Sıtma Savaş Başkanlığı, Ağız ve Diş Sağlığı Merkezi de dâhil olmak üzere 18 sağlık tesisi, 2 anaokulu, 20 ilkokul, 15 lise, 1 Mesleki Eğitim Merkezi ile 1 Halk Eğitim Merkeziz ve Akşam Sanat Okulu bulunmaktadır (Muş (Merkez) İlave+Revizyon İmar Planı Plan Araştırma Raporu, 84, 88-89, 91).

2020 y1lında halen sosyoekonomik bakımdan Türkiye'nin geri kalmış şehirlerinden biri kabul edilen (Muş (Merkez) İlave+Revizyon İmar Planı Plan Araştırma Raporu, 3) ve temel sorunu işsizlik ve nitelikli işgücü eksikliği olan Muş (Aslan ve Kaya, 2018: 275), ${ }^{24}$ sanayileşme yönelimleri bakımından son sıralarda yer almaktadır. Birçok nedeni olan bu durumun, ${ }^{25}$ şehrin fiziksel gelişimi bakımından da belirleyici bir güç hüviyetine sahip olduğunu söylemek mümkündür. Muhtelif kooperatif ve meslek odaları tarafından temsil edilmekte olup çimento, tarım makineleri, barit madeni işletmeciliği, tekstil, hazır giyim, mobilya, hazır beton, karma yem, unlu mamuller, süt ve süt ürünleri, şeker, sıcak asfalt, taş ve mıcır üretimi gibi alanları ihtiva eden çeşitli sanayi kollarının (şeker ve çimento fabrikaları dışında) küçük ve orta ölçekli olmaları (Arslan, 2018: 7879), Muş'un kentsel gelişimine sınırlı düzeyde katkı sağlayabilmelerine neden olmaktadır. Bu bakımdan şehirdeki sanayi kollarının gelişmesi ile Muş'un gelişme katsayısının yükseleceğini söylemek yanlış olmayacaktır. Son yıllardaki teşvik yasaları ile desteklenen tekstil, deri, plastik, metal işleri ve mobilya sektörlerinde gerçekleşen gelişmelerin (Arslan, 2018: 79) bu bakımdan önümüzdeki dönemlerde şehrin geleceğinde önemli roller üstleneceği düşünülebilir. Bütün bunların yanında, Türkiye'nin en büyük 3. ovasına nazır olmasına rağmen iklim koşulları, drenaj sorunu, taşkın ve erozyon gibi tehditler nedeniyle bu durumdan yeterince istifade edemeyen (Muş (Merkez) İlave+Revizyon İmar Planı Plan Araştırma Raporu, 75) şehrin geleceğinin tarım ve hayvancılık temelli ekonomik etkinlerde olduğu da genel bir kabul görmektedir. Nitekim şehrin ve ovanın karakteristiğini meydana getiren Murat Nehri üzerinde yapımı süren Alparslan I ve Alparslan II barajları ile Hidroelektrik Santrali (HES) gibi projelerin ileriki dönemlerde şehrin bu potansiyelini daha fazla açığa çıkaracağını (Aslan ve Kaya, 2018: 274; Arslan, 2018: 80) söylemekte bir sakınca yoktur. Tüm bunlara ek olarak il merkezinin denizden yüksekliği 1334 metre olup karasal iklim özellikleri taşıyan ve uzun aylar boyunca kar altında kalan Muş şehrinin kış turizmi açısından sahip olduğu ve 1960'larda fark edilen (1966 yılında Muş Kayak Kulübü kurulmuş, iki yıl sonra da Vali Vefik Kitapçıgil tarafından bir kayak evi yaptırılmıştır (1967 Muş İl Yıllı̆̆ı, 1968: 95)) imkânların (Ersungur ve Aslan, 2014: 221; Aslan ve Kendir, 2019: 169-170) gelecek yıllarda geliştirilmesi, şehrin gelişimine katkı sağlayacaktır. Güzeltepe mevkiinde faaliyet göstermekte olan kayak mer-

\footnotetext{
${ }^{24}$ TÜİK'in 2015 yılı verilerine göre, "İllere Göre Yaşam İndeksi”" sıralamasında Muş 81. sırada yer almaktadır. Bkz. Arslan ve Kendir, 2019: 168. ${ }^{25}$ Muş ilinin sosyoekonomik gelişimine engel teşkil eden nedenlerle ilgili olarak bkz. Arslan, 2018: 78.
}

kezinin bu bakımdan bir başlangıç teşkil edebileceğini not edelim.

Birinci derece deprem kuşağı içerisinde yer alan Muş'un (Muş (Merkez) İlave+Revizyon İmar Planı Plan Araştırma Raporu, 39; Tanış, 2018b: 62; Arslan, 2018: 85) kentsel gelişimin, bu özel durum nedeniyle önümüzdeki dönemlerde ovaya doğru değil, doğu ve kuzeybatı yönünde olacaktır. Nitekim belediyeden temin etmiş olduğumuz aktüel imar planı da bu yönde veriler ihtiva etmektedir. Daha önceki projeksiyon hesaplamalarının 2000 yılında 125 bin olacağını öngördüğü Muş nüfusu bu hedefe ulaşamamış olsa da, 2007 yılında Muş Alparslan Üniversitesi'nin açılması ile hızlanan demografik ve kentsel büyümenin 2030 yılında şehir için öngörülen 135 bin bandına ulaşabileceğini düşündürmektedir (Muş (Merkez) İlave+Revizyon İmar Planı Plan Araştırma Raporu, 138). Nitekim üniversitenin kurulduğu 2007'den 2019'a kadar geçen sürede nüfusun 70 binlerden 110 binlere kadar tırmanmış olması, özellikle de kent merkezi ile üniversitenin entegrasyonu daha hızlı bir biçimde temin edilebilirse, öngörülen rakamların üzerine çıkılabileceğini göstermektedir. Şehir merkezinden yaklaşık 7-8 km mesafedeki Güzeltepe mevkiinde bulunan üniversitenin Muş'un kentsel gelişimine sağlayabileceği katkıyı tam manasıyla sağlayabildiğini söylemek henüz mümkün olmamakla birlikte, belediyenin açma çalışmalarını devam ettirdiği yeni yollarla bu hedefin yakalanabileceği açıtır. Çar Deresi boyunca yapımı sürdürülmekte olup Küçük Sanayi Sitesi’ni şehir merkezine bağlayan yola ek olarak Karşıyaka Mahallesi'nin üst kısmından üniversiteye doğru yapılması planlanan yeni yol hattı projesinin tamamlanması durumunda söz konusu entegrasyon süreci de hız kazanacaktır. Muş'un kentsel gelişiminin motor kuvvetini teşkil eden ana aks Bitlis yolu boyunca ilerlemekteyse de söz konusu yol projeleri ile birlikte güneybatı yönündeki gelişim yoğunluğu da artacaktır.

\section{Kaynakça}

1967 Muş İl Yıllığı (1968). Elazığ.

1973 Muş İl Yıllığı (1973). Bingöl.

Muş 1985 Tarihli İmar Planı, Muş Belediyesi Arşivi.

1989 Muş İl Yillığı (1989). İstanbul.

Abdurrahim Şerif. (2011). Anadolu Manzaraları, Muş Ovasında. İçinde: Anadolu Mecmuast. Arslan Tekin ve Ahmet Zeki İzgöer. (Haz.). Ankara: Türk Tarih Kurumu Yayınları.

Alanoğlu, M. (2019). Nahiyeden Sancağa: 16. Yüzyılda Muş'un İdarî Yapısı. Tarih ve Kültür Bağlamında Muş Uluslararası Sempozyumu Bildirileri, 10-12 Mayıs 2018. Arzu Güvenç Saygın, Murat Saygın (Yay. Haz.), 134-160.

Arslan, Ö. (2018). Muş İli Özelinde Doğal Tarım ve Hayvancılığa Dayalı Sürdürülebilir Bir Ekonomik Gelişim. Anemon Muş Alparslan Üniversitesi Sosyal Bilimler Dergisi, 6 (1), 75-90.

Arslan, E. ve Kendir, H. (2019). Kış Turizmi Potansiyeli Açısından Muş İli'nin SWOT Analizi İle Değerlen- 
dirilmesi. Anemon Muş Alparslan Üniversitesi Sosyal Bilimler Dergisi, 7 (6), 167-173.

Aslan, A. ve Kaya, N. Ç. (2018). Proje Temelli Kalkınmaya Eleştirel Yaklaşım: Muş İli Örneği. Anemon Muş Alparslan Üniversitesi Sosyal Bilimler Dergisi, 6 (2), 269-278.

Aşgın, S. (2000). Cumhuriyet Döneminde Doğu Anadolu'ya Yapılan Kamu Harcamaları (1946-1960), Ankara: Atatürk Araştırma Merkezi Yayınları.

Atlı, C. (2019). 1950-1970 Yıllarında Muş’ta Devlet Yat1rımları. Tarih ve Kültür Bağlamında Muş Uluslararası Sempozyumu Bildirileri, 10-12 Mayıs 2018. Arzu Güvenç Saygın, Murat Saygın (Yay. Haz.), 361376.

Barbaro, J. (2016). Anadolu'ya ve Iran'a Seyahat. Tufan Gündüz. (Çev.). İstanbul: Yeditepe Yayınları.

Bedrosian, R. (2014). V-XIII. Yüzyıl Klasik Ermeni Kaynaklarına Göre Çinliler ve Çin. Mustafa Alican (Çev.). Tarih Okulu Dergisi, 7 (19), 827-836.

Biber, H. ve Çavuşoğlu, R. (2013). 2011 Yılı MuşMalazgirt Arkeolojik Yüzey Araştırması. 30. Arama Sonuçları Toplantısı, II, 303-320.

Biber, H. (2016). Demir Çağları'nda Süphan Dağı Eteklerinde Yaşam ve Ölümün Mekânsal İlişsileri. Journal Of Human Sciences, 13 (2), 3501-3520.

Biber, H. (2018). Muş İli Arkeolojik Yüzey Araştırmaları, 2009-2014. İstanbul: Hiperlink Yayınları.

Bingül, Ş. (2019). 19. Yüzyıl Osmanlı Modernleşmesi Bă̆lamında Muş Sancă̆ında Islahat Hareketleri. İçinde: Burası Muş'tur. Ercan Çağlayan. (Ed.). İstanbul: Pınar Yayıncilik.

Bingül, Ş. (2019b). 19. Yüzyılın Modernleşme Politikaları Çerçevesinde Muş ve Çevresindeki Maarif Faaliyetleri, İçinde: Tarihî ve Kültürel Dokusuyla Koğak, Mehmet Salmazzem. (Ed.). Konya: Çizgi Yayınevi.

Brant, J. (2014). 1838 Yazında Kürdistan. A. Celil Kaya. (Çev.). İstanbul: Rûpel Yayınları.

Chesnau, J. (2012). D’Aramon Seyahatnamesi. Iş1l Erverdi. (Çev.). İstanbul: Dergah Yayınları.

Cumhurbaşkanlığı Cumhuriyet Arşivi (CCA), 30-18-1-2-2$18-1$.

CCA, 30-10-0-0-178-226-7.

CCA, 30-18-1-2-80-93-10.

CCA, 30-1-0-0-134-874-2.

CCA, 30-18-1-2-140-68-15.

CCA, 30-1-0-0-73-464-3.

CCA, 30-18-1-2-364-2-17.

Çabuk, M. ve Tombul, S. (2019). Osmanlı Arşiv Belgelerine Göre Muş'taki Ermeni İhtilalcilerin Ermenilere Zulmü (1892-1906). Asia Minor Studies Journal, 7, (1), 1-14.
Çağlayan, E. (2019). Tek Parti Döneminde Muş: Imar, Iskân ve Inşa. İçinde: Burası Muş'tur. Ercan Çağlayan. (Ed.). İstanbul: Pınar Yayıncılık.

Çayın, M. ve Özer, H. (2015). Üniversitelerin İl Ekonomisine Katkısı ve Öğrencilerin Tüketim Yapısı: Muş Alparslan Üniversitesi Örneği. Dokuz Eylül Üniversitesi İktisadi ve İdari Bilimler Fakültesi Dergisi, 30 (2), 131-147.

Çiçek, B. ve Almalı, V. (2019). Yükseköğretimde İtibar: Halkın Gözünden Üniversiteye Bir Bakış. INIJOSS, 8 (1), 90-111.

Darkot, B. (1979). Muş. MEB Íslam Ansiklopedisi, 8, 744747.

Dölek, İ. ve Avcı, V. ve Harunoğulları, M. (2018). Nüfusun ve Yerleşmelerin Yükseltiye Göre Değişimi: Muş İli Örneği. Anemon Muş Alparslan Üniversitesi Sosyal Bilimler Dergisi, 6 (6), 1011-1022.

Ebü'l-Fidâ. (2017). Ebü'l-Fidâ Coğrafyası. Ramazan Şeşen. (Çev.). İstanbul: Yeditepe Yayınları.

Ersungur, Ş. M. ve Aslan, M. B. (2014). Muş İlinin Gelişme Potansiyelinin SWOT Analizi İle İncelenmesi. Atatürk Üniversitesi İktisadi ve İdari Bilimler Dergisi, 28 (4), 213-235.

Eser, M. (2013). İlk Dönem İslam Tarihinde Muş ve Çevresi. ISTEM, 11 (22), 43-67.

Eser, M. (2014). Muş İsminin Menşei Üzerine Bir Değerlendirme. EKEV Akademi Dergisi, 18 (58), 211-228.

Evliyâ Çelebi. (2010). Günümüz Türkçesiyle Evliya Çelebi Seyahatnamesi, 4/1. Seyit Ali Kahraman ve Yücel Dağlı. (Haz.). İstanbul: Yapı Kredi Yayınları.

Galtsyan, A. G. (2007). Ermeni Kaynaklarına Göre Moğollar. İlyas Kemaloğlu. (Çev.). İstanbul: Yeditepe Yayinlar1.

Gencer, F. (2019). Bitlis ve Muş'un Son Beyleri: Alaadddin Paşazadeler. İstanbul: Libra Kitap.

Gök, S. (2019). Cumhuriyet Halk Partisi İktidarında Doğu ve Güneydoğu Anadolu'da İskan Politikalarl (19231950). İstanbul: Efeakademi Yayınları.

Grousset, R. (2006). Başlangıcından 1071'e Ermenilerin Tarihi. Sosi Dolanoğlu (Çev.). İstanbul: Aras Yayınc1lik.

Halaçoğlu, Y. (2015). Ermeni Tehciri. İstanbul: BKY.

Hewsen, R. H. (2016). Pağeş/Bitlis ve Daron/Muş'un Tarihi Coğrafyası. Zülal Kılıç. (Çev.) İçinde: Hovannisian, R. G. (ed.) Bitlis ve Muş, Ankara: Aras Yayıncılık.

Hovannisian, R. (2016). Ermeni Pağeş/Bitlis ve Daron/Muş. Zülal Kılıç. (Çev.). İçinde: Hovannisian, R. (ed.) Bitlis ve Muş, Ankara: Aras Yayıncılık.

http://www.mus.bel.tr/mart-ayi-meclis-toplantisi-yapildi https://biruni.tuik.gov.tr/nufus80app/idari.zul?yil=1965.

https://biruni.tuik.gov.tr/nufus80app/idari.zul?yil=1970.

https://biruni.tuik.gov.tr/nufus80app/idari.zul?yil=1975.

https://biruni.tuik.gov.tr/nufus80app/idari.zul. 
https://biruni.tuik.gov.tr/nufus85app/idari.zul.

https://biruni.tuik.gov.tr/nufus90app/idari.zul.

https://biruni.tuik.gov.tr/nufusapp/idari.zul.

https://biruni.tuik.gov.tr/medas/?kn=95\&locale=tr.

https://musdh.saglik.gov.tr/TR,240542/hastanemizhakkinda.html

https://www.bik.gov.tr/mus-havalimaninin-adi-degisti/

http://www.alparslan.edu.tr/sayfa.xhtml?sayfa=tarihce

http://www.mus.gen.tr/haber-8994-mus-kavsaga-sultanalparslan-heykeli-dikildi-haberi.html

https://www.toki.gov.tr/illere-gore-projeler

Kara, H. (2019). Sultan II. Abdülhamid Döneminde Muş Sancağı. İçinde: Burası Muş'tur. Ercan Çağlayan. (Ed.). İstanbul: Pınar Yayıncılık.

Kardaş, S. (2019). Birinci Dünya Savaşı'nda Muş. İçinde: Burası Muş'tur. Ercan Çağlayan. (Ed.). İstanbul: P1nar Yayıncilık.

Kardaş, A. (2019). 'Bir Karış Fazla Şimendifer' Elazı̆̆ Muş Demiryolu'nun Yapım Süreci. Akademik Tarih ve Düşünce Dergisi, 6 (4), 2360-2382.

Kaynar, İ. S. (201). Muş'a Demiryolunun Geliși, Tarih ve Kültür Bağlamında Muş Uluslararası Sempozyumu Bildirileri, 10-12 Mayıs 2018, Arzu Güvenç Saygın, Murat Saygin. (Haz.). Ankara, 395-409

Kılıç, O. (2004). 1571 Tarihli Mufassal Evkaf Tahrir Defterine Göre Erciş, Bargiri (Muradiye) ve Muş Vakıflar1. Osmanlı Araştırmaları Dergisi, XXIV, 243-255.

Koçhan, N. ve Sur, C. (2003). Muş-Kepenek Urartu Kalesi. Güzel Sanatlar Enstitüsü Dergisi, 10, 57-63.

Kopar, M. (2009). Cumhuriyet Halk Partisi Döneminde Doğu Anadolu'ya Yapılan Kamu Harcamalarl ve Yatırımlar (1927-1950), Ankara: Atatürk Araştırma Merkezi Yayınları.

Kozbe, G. (1995). Muş Ovası Yüzey Araştırmalarında Ele Geçen Transkafkasya Çanak Çömleği Işı̆̆ında Bölgenin Erken Tunç Çağ'ının Yeniden Değerlendirilmesi. Arkeoloji Dergisi, 3, 35-40.

Kulağuz, B. N. (1997). Muş ve Çevresindeki Türk Mimarî Eserleri. Van Yüzüncü Y1l Üniversitesi Sosyal Bilimler Enstitüsü Yüksek Lisans Tezi.

Lynch, H. F. B. (1971). Armenia, Travels And Studies, II. The Turkish Provinces. London.

Mayevski. (2007). 20. Yüzyll Dönemecinde Rus General Mayevski'nin Türkiye Gözlemleri. Bayram Bayraktar. (Haz.). İstanbul: İnkılap Kitabevi.

Muș İl Özel İdaresi Arşivi.

Muş (Merkez) İlave+Revizyon İmar Planı Plan Araştırma Raporu. (2020). Muş Belediyesi Arşivi.

Oktay, H. (2007). Ermeni Kaynaklarında Türkler ve Mogollar. İstanbul: Selenge Yayınları.
Öney, C. (2019). Muş Sancă̆ında Misyonerlik Faaliyetleri. İçinde: Burası Muş’tur. Ercan Çağlayan. (Ed.). İstanbul: Pınar Yayıncılık.

Özalper, M. (2015). Birinci Meclis’te Muş Milletvekilleri ve Faaliyetleri (1920-1923). ASOS JOURNAL, 3 (13), 512-528.

Özdal, A. N. (2019). İmparatorlukların Gölgesinde ve Kendi Halinde: Ortaçağ' da Muş'un Toplumsal Hareketliliği ve Toplumsal Yapısı. Tarih ve Kültür Bağlamında Muş Uluslararası Sempozyumu Bildirileri, 10-12 Mayıs 2018. Arzu Güvenç Saygın, Murat Saygın (Yay. Haz.), 113-124.

Özfirat, A. (1999). 1997 Yılı Bitlis-Muş Yüzey Araştırmas1: Tunç ve Demir Çağları. XVI. Araştırma Sonuçlart Toplantısl, II, 1-22.

Özfirat, A. (2000). 1998 Yııı Bitlis-Muș İlleri Yüzey Araştırması: Tunç ve Demir Çağları. XVII. Araştırma Sonuçlart Toplantısı, II, 193-210.

Öztürk, A. ve Toprak, S. (2018). Kafkasya'dan Muş Yöresine Göçler ve Göçmenlerin İskânı (1856-1905). SUTAD, 43, 437-458.

Polat, F. A. (2019). Bir Bilim Yuvası Olarak Muş Alparslan Üniversitesi. Tarih ve Kültür Bağlamında Muş Uluslararası Sempozyumu Bildirileri, 10-12 Mayıs 2018, Arzu Güvenç Saygın, Murat Saygın. (Haz.). Ankara, 3-23.

Polonyalı Simeon. (1964). Seyahatname (1608-1619). Hrand D. Andreasyan. (Haz.). İstanbul: İstanbul Üniversitesi Edebiyat Fakültesi Yayınları.

Rothmann, M. S. ve Kozbe, G. (1997). Muş In The Early Bronze Age. Anatolian Studies, XLVII, 105-126.

Salnâme-i Vilâyet-i Bitlis, 1. Def'a (1310).

San, M. S. (1966). Doğu Anadolu ve Muş'un İzahlı Kronolojik Tarihi. Ankara: Yargıçoğlu Matbaası.

Southgate, H. (1840). Narrative Of A Tour through Armenia, Kurdistan, Persia And Mesopotamia. New York.

Sönmez, M. E. (2005). Muş Ovası ve Çevresinin Arazi Kullanımı, İstanbul Üniversitesi Sosyal Bilimler Enstitüsü Yüksek Lisans Tezi, İstanbul.

Şen, K. (2020). Muş Merkezde Yer Alan Nadide Bir Eser: Selim Paşa Taş Vakfiyesi," Atatürk Üniversitesi Türkiyat Araştırmaları Enstitüsü Dergisi, 67, 455470.

Şeref Han. (2009). Şerefname. M. Emin Bozarslan (Çev.). İstanbul: Deng Yayınları.

Şerefüddin Ali Yezdî. (2019). Emîr Timur (Zafernâme). Ahsen D. Batur. (Çev.). İstanbul: Selenge Yayınları.

Şihabeddin b. Fazlullah el-Ömerî. (2014). Mesâlikü'l-Ebsâr (Türkler Hakkında Gördüklerim ve Duyduklarım). Ahsen D. Batur. (Çev.). İstanbul: Selenge Yayınları.

Tanış, C. (2018). Osmanlı Devleti'nde Hapishane Islahatı: Muş Hapishanesi Örneği (1908-1914). Uluslararası Sosyal Araştırmalar Dergisi, 11 (57), 141-146. 
Tanış, C. (2018). Osmanlı Arşiv Belgelerinde 1903 Malazgirt Depremi. Anemon Muş Alparslan Üniversitesi Sosyal Bilimler Dergisi, 6 (1), 61-66.

Tiryaki, S. (2019). Eskiçă̆'da Muş. Iğdır Üniversitesi Sosyal Bilimler Dergisi, 19, 75-114.

Tozer, H. F. (1881). Turkish Armenia and Eastern Asia Minor. London.

Turan, O. (2004). Doğu Anadolu Türk Devletleri Tarihi. İstanbul: Ötüken Neşriyat.

Tuncel, M. (2006). Muş. DİA İslam Ansiklopedisi, 31, 368371.

Yalçın, E. S. (2009). Cumhuriyet Döneminde Doğu Anadolu'ya Yapılan Kamu Harcamaları (1960-1980). Ankara: Berikan Yayınları.
Yıldız, H. (2019). Osmanlı Modernleşme Sürecinde Muş Sancağında Ĕgitim. İçinde: Burası Muş'tur. Ercan Çağlayan. (Ed.). İstanbul: Pınar Yayıncılık.

Yiğitpaşa, D. ve Can, S. (2012). Van Müzesi Buluntuları Işığında Van-Muş Bölgesinin Erken Tunç Çağı ve Karaz Kültürü. Uluslararası Sosyal Araştırmaları Dergisi, 5 (20), 274-291.

Yuca, İ. S. (2019). Cumhuriyet Döneminde Muş'ta Spor Faaliyetleri. İçinde: Tarihsel Süreç İçerisinde Muş'ta Spor Kültürü. Ömer Kaynar. (Ed.). Ankara: Akademisyen Kitabevi.

Yurt Ansiklopedisi, (1982-1983). VIII, İstanbul. 